\title{
Rekolekcje dla osób uzależnionych od alkoholu jako przykład wyzwań pastoralnych podejmowanych w trosce o osoby społecznie wykluczone
}

\begin{abstract}
Maryjo, Królowo Polski, bq̨dź nadal natchnieniem tych wszystkich, którzy walcza o trzeźwość swych bliźnich, o trzeźwość samych siebie, o trzeźwość narodu. Szczególnie jestem wdzięczny tym, którzy podejmuja inicjatywy $w$ tej dziedzinie - zwłaszcza w miesiącu sierpniu [...]. Nie wolno tych inicjatyw ośmieszać i pomniejszać! Nie wolno! Zbyt wysoka jest stawka, o która chodzi. Wiemy to dobrze z historii. Zbyt wysoka jest stawka! I trzeba tutaj iść pod prad! Pod prąd społecznego nawyku i płytkiej opinii. Pod prąd ludzkiej słabości. Pod prądźle rozumianej wolności. Wolnośćnie została człowiekowi dana przez Stwórcę do tego, ażeby niszczył siebie i drugich. Wolność to nie jest samowola.
\end{abstract}

Jan Paweł II, Jasna Córa, 11 czerwca 1987

W niniejszym artykule autor stara się przedstawić pastoralno-homiletyczne dominanty rekolekcyjnych spotkań, analizując ich schemat z dwóch perspektyw: teologii pastoralnej (teologii praktycznej) i jednocześnie posługi kapelana Szpitala Specjalistycznego im. dr. Józefa

$1 \quad$ Ks. dr Jan Klimek, Uniwersytet Papieski Jana Pawła II w Krakowie, Wydział Teologiczny, Katedra Psychologii Pastoralnej, od 2008 r. kapelan Szpitala Specjalistycznego im. dr. J. Babińskiego w Krakowie. . 
Babińskiego w Krakowie, ze specyfiką pracy duszpasterskiej w takim miejscu. Chodzi o posługę kapelana wobec osób chorych psychicznie lub uzależnionych oraz z podwójnymi diagnozami (choroba psychiczna i jednocześnie uzależnienie) $)^{2}$.

Artykuł stara się pokazać, jak łączą się elementy teoretyczne (ogólne założenia pastoralno-homiletyczne) z realnymi działaniami (spotkania rekolekcyjne) podejmowanymi wobec osób uzależnionych w tym konkretnym Szpitalu. Stąd też dwuczęściowa struktura niniejszego opracowania.

Celem artykułu jest również swego rodzaju promocja samego wydarzenia cyklicznych rekolekcji oraz wyeksplikowanie i dowartościowanie aspektów duchowych w terapii osób uzależnionych.

2 W Szpitalu Specjalistycznym im. dr. Józefa Babińskiego leczenie osób uzależnionych rozpoczęto już w 1947. Pierwszym lekarzem i ordynatorem oddziału leczenia alkoholików był dr Zdzisław Mieniewski. Już wtedy prowadzono terapię nowatorskimi na ówczesne czasy metodami leczenia: detoksykacją, ergoterapią i metodą awersyjną. W latach pięćdziesiątych wprowadzono systematyczną psychoterapię z chorymi uzależnionymi. Od 1964 zaczęto stosować psychoterapię z rodzinami alkoholików, udoskonalając jednocześnie techniki psychoterapii indywidualnej oraz grupowej. Do zespołu psychoterapeutycznego włączono psychologów i socjologów. Pod koniec lat dziewięćdziesiątych zaproszono do zespołu terapeutycznego również kapelana. Praca zespołu oparta jest na społeczności terapeutycznej z samorządem pacjentów, radą pacjentów i sądem koleżeńskim. Prowadzi się również początkowo rehabilitację wewnątrzszpitalną i dalszą poszpitalną w klubach abstynenckich. Zasadniczym celem leczenia jest umożliwienie pacjentowi przerwanie picia alkoholu w sposób bezpieczny i humanitarny, tak aby nie zagrażało to jego życiu i zdrowiu. Pobyt na oddziale to pierwsza faza leczenia, podczas której pacjenta motywuje się, by podjął dalsze leczenie odwykowe. 


\title{
1. Założenia homiletyczno-pastoralne cyklicznych rekolekcji dla osób uzależnionych w Szpitalu Specjalistycznym im. dr. Józefa Babińskiego w Krakowie
}

\author{
Osoby uzależnione od alkoholu \\ adresatem szczególnej troski duszpasterskiej
}

Kościół nie pozostaje obojętny na los osób cierpiących z powodu różnorodnych uzależnień. Stara się pomóc potrzebującym i ich rodzinom poprzez promocję życia w trzeźwości, tworzenie duszpasterstw dla osób uzależnionych, organizację poradni życia rodzinnego, posługę słowa Bożego, wsparcie modlitewne dla osób dotkniętych chorobą alkoholową i ich rodzin oraz przez różnorakie działania charytatywne ${ }^{3}$.

Kościół w Polsce prowadzi szeroko zakrojoną działalność duszpasterską wobec osób marginalizowanych, wykluczonych, społecznie nieakceptowanych. Wpisuje się to wyraźnie w pastoralne założenia pontyfikatu papieża Franciszka ${ }^{4}$. Swoją pasterską troską otacza również osoby z problemem uzależnień. W Polsce wiele spotkań wspólnot realizujących program 12 kroków odbywa się w salkach przyparafialnych i nierzadko korzysta się na nich z infrastruktury parafialnej. Często przy sanktuariach, dekanatach i większych parafiach działają różnego rodzaju organizacje i poradnie, które mają zaoferować właśnie „pierwszą pomoc” osobom walczącym z uzależnieniem lub współuza-

3 Por. stałe inicjatywy ośrodków trzeźwościowych (prowadzonych przez instytucje kościelne): Zespół Konferencji Episkopatu Polski ds. Apostolstwa Trzeźwości, Apostoł trzeźwości. Vademecum Apostolstwa Trzeźwości. Kochająca matka zawsze trzeźwa, red. O. J. Puszkiewicz, Łomża 2014, S. 227nn.

4 W adhortacji apostolskiej Evangelii gaudium, programowym dokumencie obecnego pontyfikatu, jak twierdzi sam papież Franciszek, w wielu miejscach znajdziemy apel dotyczący aktywnej troski Kościoła o osoby wykluczone i marginalizowane. 
leżnieniem ${ }^{5}$. Można $\mathrm{w}$ nich skorzystać $\mathrm{z}$ porady psychologów, terapeutów uzależnień, doradców rodzinnych, pracowników socjalnych i prawników. Co więcej, daje to możliwość spotykania się grup samopomocowych w szczególnej bliskości przestrzeni sacrum. Umożliwia to osobom uzależnionym uczestnictwo w Eucharystii - „,źródle i szczycie życia chrześcijańskiego" (Lumen gentium, 11) - która jest dla wielu istotnym umocnieniem. W Krakowie duszpasterz trzeźwości ks. kan. Mirosław Żak organizuje pielgrzymki, dni skupienia, msze święte raz w miesiącu, rekolekcje. Według świadectw osób uzależnionych posługa duszpasterska stanowi ważny element duchowego towarzyszenia osobom zniewolonym nałogami ${ }^{6}$.

Od blisko dwudziestu lat ${ }^{7}$ pacjenci Szpitala Specjalistycznego im. dr. Józefa Babińskiego w Krakowie z Oddziału Rehabilitacji dla Uzależnionych od Substancji Psychoaktywnych ze Współistniejącymi Zaburzeniami Psychicznymi [dalej: ORU] oraz Oddziału Terapii Uzależnionych od Alkoholu, w tym Osób z innymi dysfunkcjami [dalej: OTUA] kończą swoją sześciotygodniową terapię rekolekcjami, które prowadzi kapelan ${ }^{8}$ oddziałów wraz ze wspomagającą go diakonią, w większości składającą się z trzeźwiejących alkoholików.

$5 \quad$ Aktualne dane znaleźć można w dokumentach Zespołu Konferencji Episkopatu Polski ds. Apostolstwa Trzeźwości, np. Apostoł Trzeźwości, dz. cyt.

6 Świadectwa te są głoszone w czasie cyklicznych rekolekcji, których schemat homiletyczno-pastoralny przedstawia niniejsze opracowanie.

7 Por. http://www.diecezja.pl/wierni.html (3.02.2016).

8 Posługę duszpasterską w Szpitalu Specjalistycznym im. dr. Józefa Babińskiego w Krakowie prowadzą: ks. dr kan. Jan Klimek (kapelan szpitalny, rektor Rektoratu Matki Bożej Częstochowskiej w Krakowie) oraz ks. mgr kan. Mirosław Żak duszpasterz Duszpasterstwa Trzeźwości Archidiecezji Krakowskiej (terapeuta zajęciowy na oddziałach alkoholowych, wieloletni pracownik Szpitala Specjalistycznego im. dr. Józefa Babińskiego w Krakowie). Cykliczne rekolekcje kończące okres terapii przygotowuje i prowadzi wraz z diakonią muzyczną oraz grupą osób składających świadectwa ks. Mirosław Żak. 
Zdecydowana większość pacjentów kończących terapię na oddziałach alkoholowych uczestniczy w tych rekolekcjach ${ }^{9}$, choć osób korzystających w kaplicy szpitalnej ${ }^{10} \mathrm{z}$ tej formy posługi duszpasterskiej jest więcej niż samych pacjentów. Cyklicznie wiele osób, które wcześniej ukończyły terapię (niektóre już prawie dwadzieścia lat temu), przyjeżdża na rekolekcyjne spotkania, nierzadko z całą swoją rodziną. Jest to ciekawe pastoralne zjawisko, podkreślające znaczenie rekolekcji (posługi słowa Bożego) oraz posługi kapelana (świadectwo osoby) nie tylko w trakcie terapii, ale również w okresie trzeźwienia. Wskazuje ono również na potrzebę ciągłego duchowego wsparcia alkoholików na drodze abstynencji.

Samo przygotowanie i prowadzenie rekolekcji kończących każdy cykl terapeutyczny w Szpitalu to średnio 25 godzin etatowych pracy kapelana ${ }^{11}$. Około 30 proc. etatowego czasu pracy duszpasterza uzależnień zajmuje przygotowanie i prowadzenie tej formy posługi pastoralnej.

Oprócz pacjentów kończących cykl terapii w rekolekcjach biorą udział często ich rodziny i najbliżsi. To oni na ogół stanowią ponad połowę osób obecnych na rekolekcyjnych spotkaniach. Stąd ważną rzeczą jest, aby treść rekolekcyjnych konferencji uwzględniała problemy współuzależnienia. Trzecią grupę uczestników stanowią niezwiązani terapią z ORU i OTUA trzeźwiejący alkoholicy i ich rodzi-

9 Według danych kapelanii jest to ok. 50 proc. wszystkich osób kończących terapię. Wahania procentowe są tutaj duże; w niektórych grupach z rekolekcji korzystało nie więcej niż 30 proc. pacjentów, ale w innych było to nawet 80 proc. i więcej. Każdy z sześciotygodniowych cykli kończy średnio 40 pacjentów. Od 1 stycznia 2016 ORU powiększono z 60 do 90 łóżek, stąd prognozowane dane statyczne będą większe.

10 Kaplica pw. Matki Boskiej Częstochowskiej przy Szpitalu Specjalistycznym im. dr. Józefa Babińskiego w Krakowie, w której odbywają się rekolekcje, pełni jednocześnie funkcję kościoła rektoralnego dla mieszkańców osiedla przyszpitalnego (Kraków, ul. Babińskiego 29).

11 Kapelan ORU pracuje na jedną drugą etatu. 
ny oraz osoby kończące terapię w innych ośrodkach. Informacje na temat terminów rekolekcji najczęściej czerpią z Internetu. W sumie ta trzecia grupa stanowi około 10-15 proc. wszystkich uczestników. Istotną część w jej obrębie stanowią osoby, które same nie pijąc, borykają się z problemem uzależnienia w swojej rodzinie bądź w najbliższym środowisku (pijący sąsiad, przyjaciel, współpracownik). Zdarza się, że po jakimś czasie przyprowadzają osoby uzależnione na terapię do Szpitala.

Każdy cykl rekolekcji jest trochę inny i niepowtarzalny, choć oparty na stałym pastoralno-liturgicznym schemacie. Elementami zmiennymi są przede wszystkim nieschematyczne świadectwa, które składają zaproszone na rekolekcje osoby. Minimalne przesunięcia akcentów tematycznych w konferencjach rekolekcyjnych związane są z okresami roku liturgicznego bądź z istotnymi wydarzeniami społecznymi z okresu terapii.

\section{Rekolekcje-czas zespolenia przemian}

Pierwszorzędnym celem rekolekcji kończących każdy okres terapii jest zespolenie psychicznej przemiany dokonanej na jej skutek oraz somatycznej poprawy zdrowia $\mathrm{z}$ duchowym odrodzeniem człowieka (rekonstrukcja świata wartości z ich nadprzyrodzonym źródłem) i doświadczeniem wolności od uzależnienia w kategoriach wiary. Drugorzędny cel to odkrycie działania Bożej łaski we wspólnocie poprzez sakramenty Kościoła jako szczególnego umocnienia na drodze do abstynencji.

Jak wiemy, każde dobro w życiu chrześcijanina wynika ze współpracy z Bożą łaską. Wielu z pacjentów doświadczyło szczególnej Bożej opatrzności w życiu (co podkreślają w składanych świadectwach), jednak pierwszorzędnym celem rekolekcyjnych spotkań jest zespolenie wszystkich zmian, które dokonały się w okresie terapii. Choroba alkoholowa dotyka liczne wymiary ludzkiej egzystencji. Wyraźnie wskazać można na przynajmniej cztery: somatyczny (cielesny), 
psychiczny (kognitywny i emocjonalny), społeczny (budowanie relacji międzyludzkich) oraz duchowy (obszar religijnych doświadczeń, wartości i sensu życia). Ten priorytetowy cel rekolekcji, polegający na zespoleniu procesu somatycznego (odtrucie organizmu) i psychicznego (trzeźwe myślenie i przeżywanie emocji, uwolnienie się od mechanizmu nałogowego regulowania uczuć) z duchowym (doświadczenie przebaczenia i umocnienia w Bożej łasce), a te $\mathrm{z}$ kolei z procesem relacyjnym (uzdrowienie i budowanie relacji społecznych w rodzinie i w środowisku), wyraża się w szczególnej spójności słowa Bożego, świadectwa ludzkiego i czytelnego znaku w całym pastoralnym oddziaływaniu wydarzeń czasu rekolekcyjnego.

Ramowa konstrukcja spotkań rekolekcyjnych odwołuje się do doświadczenia procesu, czyli następstwa wydarzeń (będących przyczyną lub skutkiem innych) umiejscowionych w czasie a zmierzających do określonego celu. To doświadczenie procesu zespala się z psychiczną retrospekcją osób uzależnionych i odkryciem procesu degradacji i rozwoju ich osobowości. Łączy się też z nowym doświadczeniem czasu przeżywanego w trzeźwy sposób. Szczególnym celem procesu rekolekcyjnego jest $\mathrm{z}$ jednej strony uświadomienie sobie działania Bożej opatrzności w życiu alkoholika oraz z drugiej doświadczenie spotkania ze Zmartwychwstałym Chrystusem w tajemnicy Eucharystii i odkrycia w niej obfitego źródła łaski ${ }^{12}$.

Fundamentalnym narzędziem oddziaływania rekolekcyjnego są: słowo Boże, objaśniające je słowa konferencji, dobrane treściowo pieśni i piosenki religijne (bardzo istotna rola diakonii muzycznej), świadectwa trzeźwiejących alkoholików oraz dopasowane swoim wewnętrznym wyrazem miniinscenizacje, obrazujące ewangeliczną

Ważne jest, aby człowiek uzależniony uświadomił sobie, że w najtrudniejszych momentach jego życia zniewolonego nałogiem dokonała się szczególna interwencja Boga. Chodzi tu o głębsze, poprowadzone w świetle wiary zrozumienie okoliczności towarzyszących momentowi przemiany, a następnie podjęcie zasadniczej decyzji, wyrażenie prośby o pomoc, rozpoczęcie terapii itd. 
prawdę, podejmowane przez całą grupę (np. wiązanie rąk sznurkiem, palenie przed drzwiami kościoła kartek z zapisanymi grzechami, gest przytulenia przez kapłana, podanie sobie rąk w okręgu, gest oranta, zapalenie przez penitenta po spowiedzi swojej „osobistej” świecy od paschału). Działania te wpisują się w próbę poprawienia jakości percepcji ewangelicznego słowa u uczestników rekolekcji (por. Sacrosanctum concilium, $46^{13}$ ).

\section{Homiletyka -sztuka przepowiadania (aktualizacji) słowa Bożego}

Homiletykę zaliczyć należy do subdyscyplin teologii pastoralnej ${ }^{14}$. Formułując sposoby publicznego głoszenia słowa Bożego dla współczesnego człowieka, korzysta nie tylko z osiągnięć nauk teologicznych (egzegeza, teologia biblijna, liturgika), ale również nauk społecznych i humanistycznych (psychologia, socjologia, pedagogika, retoryka, teoria komunikacji). W poprawnej i skutecznej refleksji

Ze względu na wagę słowa Bożego rodzi się konieczność poprawienia jakości homilii. Jest ona bowiem „częścią czynności liturgicznej”; ma za zadanie dopomagać pełnemu zrozumieniu oraz oddziaływaniu słowa Bożego na życie wiernych. Dlatego wyświęceni szafarze winni „dokładnie przygotowywać homilię, opierając się na stosownej znajomości Pisma Świętego". Należy unikać homilii ogólnych i abstrakcyjnych. W szczególności proszę duchownych, by głoszone słowo Boże było ściśle powiązane z celebracją sakramentalną i ż̇yciem wspólnoty, tak by słowo Boże było rzeczywistym wsparciem dla życia Kościoła. Należy mieć na uwadze katechetyczny i zachęcający cel homilii. Jest wskazane, by wychodząc od trzyletniego cyklu lekcjonarza, przedstawiano wiernym w sposób właściwy homilie tematyczne, w których omówiono by w ciągu roku liturgicznego wielkie zagadnienia wiary chrześcijańskiej. Treść do nich należy czerpaćw sposób pewny z Magisterium w oparciu o cztery "filary” określone przez Katechizm Kościoła katolickiego i niedawno ogłoszone Kompendium, a więc: wyznanie wiary, celebracja misterium chrześcijańskiego, życie w Chrystusie, modlitwa chrześcijańska. (SC 46)

14 Por. J. Twardy, Źródła przemian we współczesnej homiletyce fundamentalnej, „Śląskie Studia Historyczno-Teologiczne" 39 (2006) z. 1, S. 112-125. 
homiletycznej spotykają się bowiem dwa nurty: teologiczny i antropologiczny. Zawsze jednak homileta musi uwzględnić zagadnienie podstawowe (priorytetowe), czyli teologiczne uzasadnienie głoszenia słowa Bożego hic et nunc, oraz to, co Chrystus chce powiedzieć w tym konkretnym tekście Ewangelii. Powinien jednocześnie zastanowić się, jak to słowo wpisuje się w całą pełnię ewangelicznego depozytu i w całą historię zbawienia (harmonia prawd wiary).

W ostatnich dekadach dokonał się szczególny, podwójny zwrot w homiletyce chrześcijańskiej. Na nowo ukazano Pismo Święte jako świadectwo żywej mowy Boga do ludzi prowadzonej w dziejach zbawienia. Uwidocznił się fakt, że słowo skierowane do każdego człowieka jest aktualne i dzisiaj. W przestrzeni biblijnej słowo Boże spotyka się ze słowem ludzkim w taki sposób, że obydwa ściśle się ze sobą łączą ${ }^{15}$. W związku z tym dokonał się rozwój teologicznej refleksji w egzegezie. Wyłoniła się dyscyplina teologii biblijnej uwydatniającej kerygmat i dlatego zaczęto mówić wręcz o teologii kerygmatycznej ${ }^{16}$. Spojrzenie na Pismo Święte jako na historię zbawienia pomogło wyeksponować biblijne znaczenie słowa Bożego. Rozwój nauk biblijnych wraz ze szczególnym zwrotem antropologicznym w XX wieku ${ }^{17}$

Por. L. Scheffczyk, Von der Heilsmacht des Wortes. Grundzüge einer Theologie des Wortes, München 1966, s. 12-13.

16 Por. J. Twardy, Źródła przemian..., dz. cyt., s. 117.

17 Wiek XX był czasem szczególnego zajmowania się człowiekiem, akcentowania godności osoby ludzkiej, personalizmu i antropocentryzmu. Według Martina Bubera człowiek jest osobą kierującą się do drugiej osoby, istotą, która żyje i posługuje się słowem - człowiek to „ja” skierowane do "ty” (por. L. Scheffczyk, Von der Heilsmacht..., dz. cyt.). Ludzka egzystencja jest ściśle związana ze słowem, ma charakter dialogiczny, określa ją i interpretuje słowo (die Worthaftigkeit der menschlichen Existenz). Życie człowieka można określićjako ustawiczny dialog z innymi ludźmi, a także i z Panem Bogiem, o czym świadczą dzieje objawienia i zbawienia. Cała rzeczywistość zbawcza ma charakter dialogiczny, na dialogu opiera się objawienie, wiara, stworzenie, odkupienie, łaska i sakrament (por. L. Scheffczyk, Von der 
przyczynił się do rozwoju teologii słowa Bożego ${ }^{18}$, która przeniknęła głęboko do homiletyki.

W Kościele katolickim dokonała się jednocześnie odnowa biblijna, której początek datuje się na koniec XIX wieku, a więc od chwili ukazania się encykliki Leona XIII Providentissimus Deus (1893 rok), określonej przez Piusa XII jako wielka karta nauk biblijnych (Magna carta) ${ }^{19}$. W XX wieku Kościół wydał szereg dokumentów wskazujących na potrzebę odpowiedniej interpretacji Pisma Świętego i konieczność czerpania $\mathrm{z}$ osiągnięć egzegezy w teologii i duszpasterstwie ${ }^{20}$. Słudzy słowa Bożego powinni poznawać i stosować $\mathrm{w}$ praktyce sposoby poprawnego odczytywania biblijnego kerygmatu ${ }^{21}$.

Drugim źródłem inspiracji teologicznych w homiletyce był zapoczątkowany w XIX wieku ruch liturgiczny ${ }^{22}$. W XX wieku odnowę liturgiczną propagowali papieże: Pius X, Pius XI i Pius XII. Rozwinięta ona została na wielką skalę przez Sobór Watykański II, a jej punktem szczytowym i źródłem nowych inspiracji stała się konstytucja o liturgii świętej Sacrosanctum concilium (z 4 grudnia 1963 roku). O tej

Heilsmacht..., dz. cyt.). Odzwierciedla to teologia słowa Bożego i jego głoszenie w dziejach zbawienia.

Por. L. Scheffczyk, Von der Heilsmacht..., dz. cyt., s. 12.

Por. A. Lewek, Wspótczesna odnowa kaznodziejstwa, z. 1, Z najnowszych dziejów ruchu homiletycznego, Warszawa 1980, s. 48-52.

Por. J. Kudasiewicz, Biblia - historia-nauka. Rozważania i dyskusje biblijne, wyd. 2, Kraków 1986, s. 114-121.

Por. J. Kudasiewicz, Biblia - historia-nauka, dz. cyt., s. 106-114.

Już w połowie XIX wieku ruch liturgiczny zapoczątkował benedyktyn Prosper Guéranger (1805-1875), opat z Solesmes we Francji. Wielkie zasługi w tym względzie mają: Dom Lambert Beauduin (†1960), benedyktyn z Louvain (czasopismo „Vie liturgique”, 1909-), Pius Parsch (†1954), benedyktyn z Klosterneuburga k. Wiednia, oraz szkoła kerygmatyczna z Innsbrucka (Josef Andreas Jungmann, Missarum Sollemnia), a w Paryżu Ośrodek Duszpasterstwa Liturgicznego, wydający czasopismo „La Maison-Dieu” (por. A. Lewek, Współczesna odnowa kaznodziejstwa, dz. cyt.). 
odnowie świadczą m.in. nowe księgi liturgiczne (lekcjonarz mszalny, niedzielny, świąteczny i okolicznościowy) i obficie zastawiony stół słowa Bożego. Zestawy czytań zawierają również opis obrzędów dokonywanych przy poszczególnych sakramentach i sakramentaliach. Odnowa liturgii wprowadzona przez Sobór Watykański II, a szczególnie liturgii słowa, i obszerny zestaw czytań liturgicznych wraz z nakazem głoszenia homilii wywołały żywą refleksję teologiczną we współczesnej homiletyce ${ }^{23}$. W świetle teologii odnowionej liturgii głoszenie słowa Bożego stanowi integralną część celebracji liturgicznej i przybiera formę homilii. Bez głoszenia słowa liturgia byłaby niepełna, a jej owocność stałaby się ograniczona. W liturgii bowiem obecny jest Chrystus, który mówi przez teksty Pisma Świętego i homilii oraz działa poprzez znaki sakramentalne.

Te nakładające się dwa nurty w refleksji teologicznej doprowadziły do szczególnego kerygmatycznego zwrotu w całej teologii, a tym samym i w homiletyce. Kerygmatyczna odnowa kaznodziejskiego przepowiadania zainspirowana została przez jezuitę z Innsbrucka, Josefa Andreasa Jungmanna. W swojej książce zatytułowanej Die Frohbotschaft und unsere Glaubensverkündigung ${ }^{24}$ wysunął on postulat, by w głoszeniu kazań powrócić do biblijnego kerygmatu. Kaznodzieja powinien więc głosić to, co głosił Chrystus, a później apostołowie i ich następcy. Powinien przybliżać słowa i czyny Chrystusa, proklamować dokonane przez Niego dzieło zbawienia, a nie

Por. D. Grasso, L'annonce du salut. Theologie de la parole (tłum. $z$ wł. na franc.), Paris 1969, S. 37-41; ]. Janicki, Homilia, [w:] Słownik teologiczny, t. I, red. A. Zuberbier, Katowice 1985, s. 208-209; W. Broński, Homilia w dokumentach Kościoła współczesnego, Lublin 1999; H. Sławiński, „Dziś spełniły się słowa Pisma, któreście słyszeli”. Homilia w niedzielnym zgromadzeniu wiernych, tłum. z ang. H. Sławiński, Włocławek 2002; E. Sobieraj, Homilia w katolickiej teologii posoborowej, [w:] Eucharystia w duszpasterstwie, red. A. L. Szafrański, Lublin 1977, s. 165-253; W. Pazera, Koncepcja homilii ewangelizacyjnej, Częstochowa 2002.

24 J. A. Jungmann, Die Frohbotschaft und unsere Claubensverkündigung, Regensburg 1936, s. 60 . 
jedynie popularyzować teologię scholastyczną. Według Jungmanna kaznodzieja, znając dogmat, winien głosić kerygmat ${ }^{25}$. Propagowali to $\mathrm{z}$ kolei jego uczniowie i zwolennicy ${ }^{26}$.

Ten zapoczątkowany w latach trzydziestych XX wieku przez jezuitów z Innsbrucka ruch kerygmatyczny stopniowo ogarnął całą teologię $e^{27}$, która w ich ujęciu powinna służyć kerygmatowi, a więc poprawnemu odczytywaniu i wiernemu głoszeniu słowa Bożego. Na nowo zwróciło to uwagę homiletów na znaczenie Pisma Świętego i na potrzebę głoszenia autentycznego słowa Bożego. Przyczyniło się to również do rozwoju homiletyki materialnej, a tym samym do większego zainteresowania treścią kazań ${ }^{28}$. Podobnie katechetycy postulowali odnowę treści przepowiadania, opartej na powrocie do biblijnego kerygmatu ${ }^{29}$. Współcześnie zarówno homileci, jak i katechetycy, odczytując kerygmat, czerpią inspirację z odnowy biblijnej i liturgicznej, która uczy wiązać słowo Boże ze sprawowanym misterium, wprowadzając na drogi Chrystusowej mistagogii. Te dwa nurty przyczyniły się do rozwoju nie tylko homiletyki ${ }^{30}$, ale też i katechetyki fundamentalnej ${ }^{31}$, a tym samym do kerygmatycznej odnowy

Das Dogma sollen wir kennen, verkünden müssen wir das Kerygma (por. J. A. Jungmann, Die Frohbotschaft..., dz. cyt., s. 60). Por. J. A. Jungmann, Glaubensverkündigung im Lichte der Frohbotschaft, Innsbruck 1963, s. 58-66; D. Crasso, L'annonce du salut, dz. cyt., S. 31-35.

Por. V. Schurr, Kerygmat i dogmat, [w:] Concilium. Międzynarodowy Przegląd Teologiczny. Wybór artykułów 1-10, 1966/7, Poznań-Warszawa 1969, s. 178-183.

Por. A. Lewek, Współczesna odnowa kaznodziejstwa, dz. cyt., s. 28-35; D. Grasso, L'annonce du salut, dz. cyt., s. 35-37.

Por. H. Simon, Przepowiadanie biblijne, [w:] Biblia w nauczaniu chrześcijańskim, red. J. Kudasiewicz, Lublin 1991, s. 52-57.

Por. G. Kusz, Biblia w katechezie wczoraj i dziś, [w:] Biblia w nauczaniu chrześcijańskim, dz. cyt., s. 90-96; A. Lewek, Współczesna odnowa kaznodziejstwa, dz. cyt., s. $57-59$. Por. H. Simon, Przepowiadanie biblijne, dz. cyt., s. 58n; D. Grasso, L'annonce du salut, dz. cyt., s. 37-41.

31 Por. G. Kusz, Biblia w katechezie..., dz. cyt., s. 96n. 
całej teologii pastoralnej, której są integralną częścią jako dyscypliny praktyczne.

Rekolekcje, które od blisko dwudziestu lat prowadzone są w kaplicy szpitalnej dla oddziałów alkoholowych, w swojej formule (biblijne treści i sposoby ich ukazywania) bardzo czytelnie wywodzą się właśnie z tej kerygmatycznej odnowy. Słowo Boże bowiem bardzo mocno zespala się w nich z celebracjami, których celem jest jak najpełniejsze przeżycie Eucharystii ${ }^{32}$, a treści biblijne wybrane do rekolekcyjnych refleksji idealnie wpisują się w kerygmat chrześcijański, ze szczególnym uwydatnieniem wolności jako niezwykłego daru dla odkupionych męką, śmiercią i zmartwychwstaniem Chrystusa. Są prawdziwie doświadczeniem mistagogicznym, w którym kapłan poprzez słowo i celebracje dosłownie prowadzi uczestników ku tajemnicom wiary i Eucharystii.

\section{Rola i znaczenie rekolekcji w duchowym rozwoju człowieka wierzącego}

Czas rekolekcji dla każdego chrześcijanina to chwila refleksji nad własnym życiem duchowym i religijnym, moment intensywnego zaangażowania w swój rozwój wewnętrzny oraz nawiązania i odnowienia osobowej relacji z Jezusem jako Panem i Zbawicielem naszego życia. To właśnie z uwagi na intensywność doświadczeń, które ze sobą niosą, i stopień zaangażowania, którego wymagają od uczestników, są one prowadzone w ostatnich dniach cyklu terapeutycznego. Chodzi tu nie tylko o jak najlepszą kondycję psychofizyczną uczestników (dobrostan pacjentów terapii odwykowej), ale również o poziom wewnętrznej motywacji do życia w wolności od uzależnienia, do trwania $\mathrm{w}$ abstynencji.

32 Właśnie aby podkreślić znaczenie Eucharystii i jej wyjątkowość, jest ona sprawowana tylko jeden raz w ciągu rekolekcyjnych dni (piątek, sobota i niedziela). 
Osobiste decyzje związane z rekolekcyjną formacją mają nie tylko pogłębić relację z Jezusem, ale podlegają także procesowi rozwoju duchowego. Za Sługą Bożym Franciszkiem Blachnickim można powiedzieć, że jest to formowanie postaw dojrzałego chrześcijanina poprzez „pedagogię nowego człowieka” ${ }^{33}$. Ów nowy człowiek to obraz odczytany z kart Biblii - stwórczy zamysł Boga wobec człowieka (por. Rdz 1 - 2). Cała biblijna koncepcja nowego człowieka, a co za tym idzie - nowej kultury, oparta jest na fakcie wyzwalającej mocy Chrystusowego dzieła odkupienia, dzięki któremu zostaliśmy wyswobodzeni do wolności dzieci Bożych ${ }^{34}$. Takie wyzwolenie dokonuje się przede wszystkim przez poznanie i zaakceptowanie prawdy jako naczelnej wartości w życiu człowieka, tak jak to napisał św. Jan: „Poznacie prawdę, a prawda was wyzwoli” (J 8, 32). Nie oznacza to przy tym całkowitej samowoli, lecz wynikające z poznania i wolnego wyboru uzależnienie się od prawdy ${ }^{35}$.

Sługa Boży Franciszek Blachnicki zwracał jednocześnie uwagę, że rozważnie słowa Bożego w odniesieniu do konkretnych wydarzeń osobistego życia każdego człowieka uobecnia to słowo jako indywidualne doświadczenie jednostki - staje się ono żywym słowem dla mnie. Kluczowa okazuje się jednak wewnętrzna dyspozycja człowieka do utworzenia przestrzeni, w której będzie mógł działać Boski Ruah ${ }^{36}$. Spotkania kapelana w czasie całego cyklu terapeutycznego z osobami uzależnionymi mają na celu m.in. stworzenie owej wewnętrznej przestrzeni; są więc też rozłożonym w czasie przygotowaniem osób uzależnionych do rekolekcyjnych spotkań.

F. Blachnicki, Charyzmat „Światło-Życie”. Teksty podstawowe, Lublin 1996, s. 31. Por. R. Balunowski, Idea „nowego człowieka” w Ruchu Światło-Życie, Lublin 1986.

Por. Rz 8, 14-15.

Por. F. Blachnicki, Nowa kultura, [w:] Oaza Rekolekcyjna Diakonii ]edności Ruchu Światło-Życie, Światło-Życie 1987, s. 163-168.

Por. F. Blachnicki, Świętość..., dz. cyt., s. 16-20. 
Sługa Boży Franciszek Blachnicki, poruszając zagadnienie ludzkiej wolności, uważał, że większość ludzi „żyje poniżej tego, kim powinni być" ${ }^{37}$. Biblijny opis grzechu pierworodnego ukazuje, iż człowiek nie potrafi posługiwać się wolnością w sposób zamierzony przez Stwórcę. Często uzurpuje sobie prawo do niezależności wobec Boga i do życia według zasad odrzucających Boże nakazy, gdyż są one rozumiane jako ograniczenie tej źle pojmowanej wolności. W konsekwencji to człowiek czyni siebie samego jedynym sędzią orzekającym, co jest dobre, a co złe. Ale tak subiektywnie pojmowana wolność staje się dla niego zgubna, prowadzi go bowiem do uzależnień i grzechu. Taka geneza uzależnienia, utraty wolności i grzechu opracowana w niezwykłej syntezie przez Sługę Bożego Franciszka Blachnickiego stanowi teologiczny fundament rekolekcyjnych konferencji ${ }^{38}$.

Natomiast wyzwolenie w myśli Blachnickiego można przedstawić na trzech różnych, ale ściśle ze sobą powiązanych płaszczyznach: fundamentalnej, ogólnej i szczegółowej ${ }^{39}$. Pierwsza z powyższych płaszczyzn wyzwolenia - płaszczyzna fundamentalna - polega na wyzwoleniu człowieka z niewoli Szatana, a co za tym idzie - z niewoli grzechu, lęku i zakłamania. Nieprzypadkowo te rodzaje zniewolenia określa się jako główne. Każde inne ma charakter wtórny, jest pochodną tych największych i najbardziej szatańskich. Mówiąc o tych zniewoleniach, nie sposób pominąć oczywistego, jak się wydaje, fundamentu wyzwolenia, którym jest Jezus Chrystus, wyzwalający człowieka w głębi jego istoty. „Konstytucją” wyzwalania są słowa Chry-

37 Por. F. Blachnicki, Prawda-krzyż-wyzwolenie. Ku polskiej teologii wyzwolenia, Carlsberg 1985, S. 39-41.

38 Cykliczne spotkania kapelana - terapeuty uzależnień - z pacjentami oddziału w ramach sześciotygodniowego cyklu terapii naprowadzają osoby leczone z uzależnienia na tak rozumianą genezę swojego nałogu.

39 Por. P. Oskwarek, Droga nowego człowieka według 10 drogowskazów Ruchu Światto-Życie formą wcielenia eklezjologii Soboru Watykańskiego II, Wrocław 2009, s. 176. 
stusa z Ewangelii według św. Jana: „Poznacie prawdę, a prawda was wyzwoli” (J 8, 32). Dlatego zestawieniu Szatan i pochodzącemu od niego zakłamaniu, grzechowi i lękowi należy przeciwstawić inne zestawienie: Chrystus Zwycięzca, będący Prawdą, i Jego zbawcze dary: łaska uświęcająca i pewność wiary. Tylko takie przeciwstawienie ma sens, gdy się mówi o wyzwoleniu ${ }^{40}$.

Następną płaszczyzną, na której dość wyraźnie ujawnia się wyzwolenie, jest płaszczyzna ogólna. Ukazuje się ona po przeanalizowaniu najbardziej charakterystycznych problemów współczesnego człowieka. To w nią właśnie wpisuje się złożony problem uzależnienia. W czasie nauk rekolekcyjnych i wcześniejszych spotkań kapelana z pacjentami wymiary zniewolenia alkoholowego opisuje się w świetle koncepcji degradacji osobowości stworzonej przez Sługę Bożego Franciszka Blachnickiego. Mówił on o czterech wymiarach degradacji ${ }^{41}$ :

a) Człowiek zdezintegrowany - to człowiek będący produktem współczesnej cywilizacji. Jest osobą wewnętrznie rozbitą, nieskoordynowaną. Zdezintegrowana jest sfera poznawcza (umysłowa) i wolitywna. Istnieje rozdźwięk pomiędzy prawdą poznaną a działaniem i postawą życiową oraz pomiędzy wiedzieć a być. Człowiek jest niekonsekwentny pomimo tego, iż wie, co i jak powinien czynić. Prawdy nie przeżywa się już jako siły normatywnej, domagającej się posłuchu i poddania jej wymogom życia. Przyczyny tej dezintegracji mogą być zewnętrzne i wewnętrzne. Zewnętrzne to narzucanie kłamstwa przez terror polityczny czy inny, np. terror opinii publicznej, powodujący lęk przed mówieniem i czynieniem prawdy. Wewnętrzne z kolei to uleganie namiętnościom, słabościom i przywiązaniom, co powoduje stawianie tego, co przyjemne, ponad to, co prawdziwe i słuszne. Skutkiem działania tych przyczyn jest rozbicie człowieka, żyjącego w jakiejś głębokiej schizofrenii ducha. 
b) Człowiek konsumpcyjny - to człowiek jednostronnie nastawiony na konsumpcję dóbr materialnych, zaprzęgnięty w złożone procesy produkcji. Wyścig produkcji i konsumpcji prowadzi do sztucznego poszerzania skali potrzeb oraz ciągłego podnoszenia ich poziomu. W efekcie dochodzi do nadprodukcji i kryzysu gospodarczego. Ostateczną ofiarą tego systemu jest człowiek, który przez jednostronne nastawienie na konsumpcję staje się pasywny, mało aktywny i nietwórczy. Nie widzi on celu życia w tworzeniu, zdobywaniu wyższych wartości, ale w używaniu dóbr materialnych i zmysłowych. Wrodzona naturze ludzkiej dążność do Absolutu i doskonałości prowadzi do wynaturzeń w postaci alkoholizmu, narkomanii lub dewiacji seksualnej. Dzieje się tak dlatego, że pragnienie użycia łączy się $\mathrm{z}$ dążeniem do jego potęgowania w nieskończoność. Pojęcie życie zostaje zastąpione słowem użycie.

c) Człowiek sukcesu - to kolejne wypaczenie współczesnej cywilizacji. Chodzi o zniewalający ideał człowieka sukcesu, odartego ze wszelkiej wartości osoby i wspólnoty, dla którego liczy się na pierwszym miejscu sukces materialny, a nie osobowy czy rodzinny, zaś na piedestale życia stawia własne ego bez jakichkolwiek ograniczeń związanych z budowaniem wspólnoty. Ktoś taki koncentruje wszystkie swoje siły i dążenia ku osiąganiu wyników w jakiejś wąskiej, wyspecjalizowanej dziedzinie i mierzy swoją wartość tymi osiągnięciami. Również społeczeństwo ocenia go w świetle danego dokonania. Nie liczą się więc cechy jego charakteru, wartość jego osobowego zaangażowania, tylko jego wyczyn, jego osiągnięcie przynoszące sławę, podziw, poklask lub inne doraźne korzyści. W ten sposób znów naturalne dla człowieka dążenie do doskonałości zostaje sprowadzone do wąskich, specjalistycznych wyczynów bądź rekordów, które rzadko doskonalą całego człowieka.

d) Człowiek stada - czyli człowiek zmanipulowany. Wszystkie powyżej ukazane przejawy i tendencje prowadzą do współczesnej depersonalizacji istoty ludzkiej, do jej uprzedmiotowienia. Ich rezultatem jest człowiek stada, człowiek masy, człowiek bez własne- 
go ,ja”. Taki ktoś staje się tylko przedmiotem wielorakich manipulacji. Myśli on i działa według sloganów, które słyszy w środkach masowego przekazu. Kieruje się w postępowaniu modą, panującą opinią, trendem. Bezkrytycznie czyni to, co inni, tylko dlatego, że inni to czynią, bez własnej, osobistej refleksji i motywacji. Człowiek taki jest niewolnikiem, manipulowanym przez innych, zależnym od różnych ośrodków dyspozycyjnych czy społecznych mechanizmów.

Na tak sformułowanych i scharakteryzowanych płaszczyznach wyzwolenia - fundamentalnej i ogólnej - można przystąpić do określenia płaszczyzny szczegółowej, tzn. do określenia konkretnych wymagań, które mogą pomóc w pracy nad sobą oraz w doprowadzeniu człowieka uzależnionego do wzrastania w coraz większej wolności dziecka Bożego ${ }^{42}$.

Zadaniem rekolekcyjnych spotkań jest nie tylko poznanie genezy uzależnienia i jego mechanizmów, ale poprowadzenie ku źródłom wolności. Te z kolei znajdują się w Bożej prawdzie.

\section{Znaczenie rekolekcji dla osób walczących z chorobą alkoholową}

Pełna duchowa przemiana nie jest do osiągnięcia wyłącznie ludzkimi zdolnościami - to owoc działania Ducha Świętego w życiu każdego chrześcijanina. W sposób istotny odróżnia to postawę człowieka wierzącego od niewierzącego, który sam wytyczając sobie ideały, stara się je osiągnąć przy pomocy dostępnych mu możliwości. Człowiek wierzący, szczególnie zaś osoba doświadczająca swojej ułomności i grzechu, winna ufnie powierzać się miłosierdziu Boga i otwierać się na działanie łaski Bożej. Jest to początek nowego życia i nowej duchowej postawy. 
W słowie Bożym przygotowywanym na potrzeby głoszenia rekolekcji wobec osób uzależnionych i trzeźwiejących alkoholików nurt antropologiczny musi być bardzo mocno wyakcentowany i specyficznie zestawiony. Analiza egzystencjalna życia osób uzależnionych prowadzona $\mathrm{w}$ światle wiary, bogato ilustrowana biblijnymi przykładami, dotyczy nie tylko osób doświadczonych zniewoleniem, z wieloma deficytami osobowości, ale również i ich rodzin (istotny problem współuzależnienia). Bowiem przeżywanie uzależnienia z jego egzystencjalnymi konsekwencjami stoi w jawnej sprzeczności z ewangelicznym orędziem o wolności człowieka odkupionego męką i śmiercią Zbawiciela. Dlatego też domaga się bardzo wyraźnej konfrontacji słowa Bożego - ewangelicznego orędzia wolności - ze słowem ludzkim, opisującym bezradność i dramat zniewolenia.

Bardzo ważne jest, aby to słowo ludzkie głoszone było jako słowo świadectwa, wypowiadanego przez ludzi będących od wielu lat na drodze abstynencji ${ }^{43}$. „Mechanizm projekcji i zaprzeczeń" ${ }^{44}$ często blokuje doświadczenie prawdy w życiu ludzi dotkniętych chorobą alkoholową. Społeczna i moralna ruina życia alkoholika (i często jego najbliższego otoczenia), będąca owocem długoletniego zmagania się $\mathrm{z}$ uzależnieniem, odbiera fundamentalną nadzieję, że jeszcze może być lepiej. Prowadzi to do destrukcji obrazu miłosiernego i przebaczającego Boga jako troskliwego Ojca. Dla alkoholików potrzeba mocnego słowa, a ostatecznie jest nim tylko ewangeliczne orędzie. Świadectwa osób będących na drodze abstynencji są w cyklu reko-

43 W cyklicznych spotkaniach rekolekcyjnych w kaplicy Szpitala im. dr. J. Babińskiego w Krakowie zawsze dobierane są osoby składające takie świadectwa. Co więcej, wielu trzeźwiejących alkoholików regularnie od wielu lat przybywa na cykliczne rekolekcje, samą już tylko swoją obecnością dając świadectwo trwania w trzeźwości.

44 Psychologia. Podręcznikakademicki, t. 1, Podstawy psychologii, red. J. Strelau, Gdańsk 2001, s. 491nn. 
lekcyjnych konferencji bardzo ważne, bowiem ukazują autentyzm i dramat uzależnienia. Co więcej, w namacalny sposób przekonują, że jednak może być inaczej, zapalają światło nadziei, podprowadzają pod drzwi wolności. Ale te drzwi wolności otwiera jedynie ewangeliczne orędzie, którego moc wypływa z paschalnego misterium Jezusa Chrystusa.

\section{Istota rekolekcji dla osób uzależnionych - powrót do chrześcijańskiego kerygmatu}

Posługa słowa wobec chorych na chorobę alkoholową to, jak wspomniano, powrót do chrześcijańskich źródeł - czyli głoszenie kerygmatu $\mathrm{z}$ jego przesłaniem o odkupieniu, a więc prawda o uwolnieniu człowieka z jarzma grzechu i zła oraz z jego skutków. To przede wszystkim ukazanie Boga jako Ojca czekającego na grzesznika i zawsze przebaczającego. W encyklice Fides et ratio św. Jan Paweł II napisał, że

[...] refleksja teologiczna w Kościele ma służyć przede wszystkim głoszeniu wiary i katechezie. Głoszenie, czyli kerygmat, wzywa do nawrócenia, ukazując prawdę Chrystusa, którą wieńczy Jego Misterium paschalne: tylko w Chrystusie bowiem możliwe jest poznanie pełni prawdy, która zbawia. (FR 99)

W życiu człowieka uzależnionego zawsze dochodzi do dramatu wielowymiarowego zakłamania, również zakłamania obrazu Boga. Stąd tematy rekolekcyjnych rozważań czerpać trzeba z krystalicznego źródła ewangelicznego przesłania. Bardziej z kerygmatu niż dogmatu, raczej z fundamentów chrześcijaństwa niż z pełni depozytu objawienia.

Ewangeliczny (Jezusowy) opis Boga jako oczekującego i wybaczającego Ojca oraz inne, paralelne przypowieści i obrazy mają za zadanie odbudować właściwe pojęcie Boga w umysłach osób uzależnionych, 
a także wzmacniać poprzez religijną nadzieję ich samoocenę. U alkoholików ta samoocena jest na ogół zaniżona, co wiąże się z doświadczaniem deficytów, które generują uzależnienie. Właściwie kształtowana religijność z teologicznym obrazem człowieka (imago Dei) stanowić może duchowy fundament, wzmacniający zasoby psychiczne osób uzależnionych. Stąd tematem wprowadzającym w rekolekcyjne spotkania winna być prawda: Bóg jest miłością, Bóg mnie kocha, jestem ukochanym dzieckiem Boga.

Dla ks. Franciszka Blachnickiego Chrystus ukazany jest w Nowym Testamencie przede wszystkim jako Zbawiciel pełen miłosierdzia wobec słabego i grzesznego człowieka:

Od człowieka oczekuje nie tyle sukcesów w pracy nad sobą i uświęcaniu się, ile wiary i zbawczej ufności w oparciu o uznanie swojej słabości. W codziennym życiu - pisał dalej - spotykamy się z wypaczonym, niezgodnym z Ewangelią obrazem Chrystusa. Występuje on jako Święty Bóg i Sędzia, który skrupulatnie liczy wszystkie ludzkie dobre uczynki, aby za nie wynagrodzić, oraz ludzkie uchybienia i grzechy, aby za nie ukarać. [...] Problem właściwej relacji do Chrystusa - Zbawiciela - odgrywa kluczową rolę. [...] Dlatego po ukazaniu obrazu Jezusa Chrystusa jako Pana, który ma kierować naszym życiem, koniecznie musimy ukazać jako pełnego miłosierdzia Zbawiciela, który podnosi nas, gdy upadamy, i wyprowadza z bezdroży, gdy błądzimy ${ }^{45}$.

W rekolekcjach prowadzonych dla ludzi uzależnionych szczególnie ważne jest właśnie przedstawienie kerygmatycznego orędzia wolności jako daru dla człowieka zniewolonego. Jego fundamentem są słowa Jezusa: „Jeżeli będziecie trwać w nauce mojej, będziecie prawdziwie moimi uczniami i poznacie prawdę, a prawda was wyzwoli” (J 8, 31-32). Jak pisał Sługa Boży Franciszek Blachnicki, tylko 
w Duchu Świętym (który doprowadza nas do całej prawdy) możemy tak przyjąć Chrystusa, który jest Światłem, i tak się z Nim zjednoczyć, że stanie się On naszym Życiem. Na tym polega nowe życie. W owej symbolice światła i życia widział ks. Franciszek podstawowy charyzmat $^{46}$. Ten zaś kerygmatyczny zwrot w swej istocie wpisuje się w szersze doświadczenie nowej ewangelizacji, którym żyje w naszej epoce Kościół.

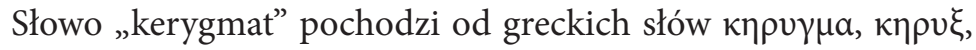
$\kappa \eta \rho v \sigma \sigma \omega$, które należy tłumaczyć jako: proklamowanie, pełnienie urzędu herolda ${ }^{47}$, ogłaszać, przepowiadać (por. Mt 12, 4; Łk 11, 32; $\mathrm{Rz} 16,25)^{48}$. W skazuje na treść głoszoną i zarazem na samą czynność głoszenia. W terminologii biblijnej, ze szczególnym uwzględnieniem Nowego Testamentu, oznacza głoszenie słowa Bożego. Czasownik

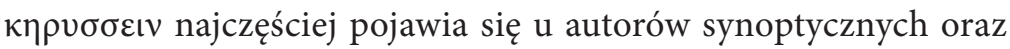
w listach św. Pawła i zawsze związany jest z czynnością przepowiadania Dobrej Nowiny o Chrystusie przez apostołów oraz ich uczniów ${ }^{49}$. Jako rzeczownik ( $ґ \rho v \gamma \mu \alpha)$ najczęściej oznacza głoszenie prawdy o Jezusie z wyakcentowaniem Jego zmartwychwstania oraz obecnej w jego nauce mocy Bożej ${ }^{50}$.

W perspektywie homiletyczno-pastoralnej pojęcie kerygmatu zawsze oznacza publiczne i uroczyste głoszenie zbawienia. Dokonało się ono w Jezusie Chrystusie, który poprzez swoją śmierć i zmartwychwstanie odkupił człowieka i jednocześnie całym życiem (każdym słowem i czynem) objawił nam Ojca. To głoszenie zbawienia

Por. F. Blachnicki, Charyzmat „Światło-Życie”. Teksty podstawowe, Lublin 1996, s. 77. Por. ]. Homerski, Kerygmat, [w:] Katolicyzm A-Z, red. Z. Pawlak, Łódź 1989, s. 208. Por. X. Léon-Dufour, Stownik Nowego Testamentu, tłum. K. Romaniuk, Poznań 1981, S. 339.

49 Por. B. Pylak, Teologia kerygmatyczna, [w:] W. Granat, Dogmatyka katolicka. Tom wstępny, Lublin 1965, s. 179-181 (Towarzystwo Naukowe Katolickiego Uniwersytetu Lubelskiego, 77).

Por. B. Pylak, Teologia kerygmatyczna, dz. cyt., s. 180. 
nierozerwalnie jest złączone $\mathrm{z}$ wezwaniem do nawrócenia i chrztu ${ }^{51}$. Ewangelia stanowi zapis właśnie tego dzieła. Głęboka teologiczna synteza dotycząca fundamentów ewangelicznego orędzia jest owocem ruchu kerygmatycznego w Kościele ${ }^{52}$.

W życiu osób uzależnionych rekolekcje wieńczące czas terapii to szczególna droga całościowego (wewnętrznego i zewnętrznego) nawrócenia i niejako moment powtórnych narodzin do życia w wolności od nałogu. To ich osobiste i często dramatyczne doświadczenie egzystencjalne związane $\mathrm{z}$ uzależnieniem głęboko wpisuje się w ramy kerygmatycznego orędzia. Nowe życie musi mieć jednakże swoje źródło, musi mieć swego dawcę, dawcę nowego życia. Dla człowieka wierzącego a uzależnionego dawcą nowego życia może być tylko Chrystus. Samo doświadczenie zniewolenia i dramatycznej bezradności zespala się przy wchodzeniu na drogę abstynencji ze szczególnym doświadczeniem mocy Bożej, która przenika życie człowieka i dociera do jego świadomości poprzez ewangeliczne orędzie.

Por. ]. Kudasiewicz, A. Zuberbier, Kerygmat, [w:] Słownik teologiczny, dz. cyt., s. 246 247.

52 Ruch kerygmatyczny rozwijał się od XIX wieku w twórczości takich autorów jak: B. Overberg (1754-1826), J. M. Sialer (1751-1832) i j. B. Hirscher (1788-1865). Akcentował znaczenie Pisma Świętego, które jest źródłem i podstawą wszelkiej katechezy. Szczytowy okres kierunku przypada na lata 1936-1960, z przełomową publikacją J. A. Jungmanna z tego okresu: Die Frohbotschaft und unsere Claubensverkündigung. Jungmann podkreślił w niej bardzo istotny element przepowiadania, które nie może być tylko popularyzowaniem teologii, ale musi głosić Dobrą Nowinę o Jezusie Chrystusie. Ruch kerygmatyczny przypomniał na nowo zapomniane pojęcia: słowo Boże, kerygmat, objawienie, chrystocentryzm, osobowy dialog Boga z człowiekiem. Dzięki rozwojowi teologii kerygmatycznej zwrócono uwagę na istotną rolę Pisma św. w życiu całego Kościoła (jako wspólnoty), ale również w życiu poszczególnych wiernych. Można domniemywać, że to właśnie ruch kerygmatyczny położył fundamenty pod soborowe postulaty związane z nowym sposobem przepowiadania. 
Język kerygmatu posiada jeszcze jedną ważną cechę - jest ze swej natury językiem świadectwa ${ }^{53}$. Odzwierciedlał on życie Kościoła zwiastującego dobrą nowinę o zbawieniu. Katecheza ta głosiła bowiem orędzie zbawcze realizujące się w słowach i czynach wspólnoty Kościoła apostolskiego. Do tych świadectw zaliczały się także życiorysy świętych i świadków wiary na przestrzeni dziejów wspólnoty wierzących ${ }^{54}$.

Świadectwa trzeźwiejących alkoholików wygłaszane w czasie rekolekcyjnych spotkań zarówno swym językiem przekazu (warstwa werbalna), jak i treścią (prawda egzystencjalna) wpisują się właśnie w kerygmatyczny fundament chrześcijańskiego orędzia. To nie język spekulatywnej teologii, to słowo człowieka, który jest przekonany, że

[...] dotknął go Boży palec. Że w najgorszym momencie jego osobistego upadku, gdy zawalił się cały jego świat, gdy ogarnął go mrok nadchodzącej śmierci, sam Chrystus - Wszechmocny i Żyjący - podał mu rękę

\section{Kerygmat a nowa ewangelizacja}

Nowa ewangelizacja to głoszenie zbawienia w Chrystusie osobom ochrzczonym, które w swoim życiu odeszły od praktyk religijnych i chrześcijańskiego życia, często żyjąc tak, jakby Boga nie było. Wzywał do niej św. Jan Paweł II w czasie synodów biskupów w Europie W 1991 oraz w 1999 roku $^{56}$. Na ogromne znaczenie nowej ewangelizacji

Zagadnienie świadectwa szeroko omawia G. Dziewulski w: Świadectwo motywem wiarygodności Kościoła, Lublin 1995.

Por. E. Młyńska, Język a podstawowe modele katechezy, [w:] Język katechezy, red. R. Przybylska, W. Przyczyna, Tarnów 2008, s. 87.

Słowa zaczerpnięte z jednego ze świadectw rekolekcyjnych spotkań.

Por. Jan Paweł II, adhort. apost. Ecclesia in Europa, 2. 
zwracał również uwagę papież Benedykt XVI, a szczególnym gestem jej służącym było ogłoszenie Roku Wiary. Aby głosić Ewangelię tym, którzy odeszli od wiary, konieczny jest powrót do kerygmatu, przekazującego główne orędzie Ewangelii o miłosiernej miłości Boga względem grzesznego człowieka. Bowiem, jak mówi papież Franciszek, prawda o miłosierdziu Boga jest fundamentem Ewangelii, a więc kerygmatem chrześcijaństwa ${ }^{57}$. Dar nowego życia przyjmowany jest przez wiarę wyrażoną w nawróceniu oraz przez przyjęcie chrztu bądź w przypadku osób już ochrzczonych - przez odnowienie tego sakramentu, m.in. poprzez uznanie Jezusa jako osobistego Pana i Zbawiciela (por. Rz 10, 9-10).

\section{Orędzie ewangelizacyjne a wolność człowieka}

W istotę człowieczeństwa została wpisana wolność jako zdolność do podejmowania decyzji, która nie jest powodowana naciskiem zewnętrznym czy wewnętrznym (jak ma to miejsce u zwierząt, które podlegają instynktom i popędom $)^{58}$. Być wolnym to posiadać zdolność do podejmowania decyzji w oparciu o świadomość tego, co się robi, dlaczego podejmuje się te działania oraz jakie one przyniosą skutki. Wolność nie jest dowolnością ani samowolą. Odpowiedzialne podejmowanie świadomych decyzji zawsze dokonuje się pod wpływem przyjętego systemu wartości i obranych celów. Wolność, w tym wyboru, łączy się z koniecznością typowania pomiędzy danymi wartościami, założonymi celami. Człowiek realizuje siebie poprzez podejmowane decyzje, które są sposobem jego urzeczywistniania się w społeczeństwie i świecie.

57 Takie przesłanie zawiera bulla Misericordiae vultus, którą papież Franciszek ogłosił Jubileusz Roku Miłosierdzia.

58 Por. H. Ćmiel, Teologia moralna szczegółowa, Częstochowa 2008, s. 483nn. 
Człowiek od początku historii może zaobserwować, że wolność jest wielkim darem, niezwykle wartościowym i wyjątkowym. Jest też ona jednocześnie źródłem zagrożeń. Podejmowane decyzje zawsze warunkują czynniki zewnętrzne i wewnętrzne, a także sytuacja społeczna. Mogą one w konsekwencji prowadzić do zagrożenia, jakim jest utrata wolności lub niewłaściwe jej wykorzystanie. Zdolność podejmowania decyzji, a więc również wolność i wola człowieka, jest nierozerwalnie związana $\mathrm{z}$ jego osobowością, dojrzałością i całym kontekstem egzystencjalnym.

\section{Analiza schematu i treści rekolekcji prowadzonych w kaplicy Szpitala Specjalistycznego im. dr. Józefa Babińskiego w Krakowie}

W rekolekcjach prowadzonych w Szpitalu korzysta się nie tylko z kanonów przepowiadania słowa, ale wykorzystuje się również inne elementy, takie jak komentarz do słowa Bożego, słowo świadectwa, przesłanie diakonii muzycznej i zestawy różnych symboli oraz gestów, które mają podkreślić znaczenie wydarzenia (zapalenie paschału, całowanie krzyża, wiązanie rąk sznurem, co symbolizuje zniewolenie grzechem i związek grzechu z chorobą alkoholową, oraz rozwiązywanie ich, zapalenie świec po spowiedzi św., zapisywanie karteczek z grzechami i ich publiczne spalenie po spowiedzi św.).

Każde rekolekcje to bardzo szczególny czas i tak powinien być on przeżywany. To czas odnowienia i pogłębienia relacji z Bogiem (wymiar wertykalny) i z bliźnimi (wymiar horyzontalny), to niezwykły moment doświadczania Kościoła jako wspólnoty ${ }^{59}$.

Według ks. Franciszka Blachnickiego Kościół przez samą etymologię greckiego słowa ekklesia oznacza w sposób istotny społeczność, wspólnotę (koinonia, communio, communitas, consortium), a jest to społeczność tych, których Bóg wywołał z upadłego w grzech świata do zbawczego zasięgu łaski. Szczegółowe wyjaśnienie słowa ekklesia odnajdujemy w: Encyklopedia Kościoła, t. 1, A-K, 
Rekolekcje to jednocześnie czas dostrzeżenia własnych braków (deficytów) i konfrontacja ze swymi wadami. Pomocą w owocnym przeżyciu tego okresu jest zawsze wspólnota, której zawiązanie następuje na początku rekolekcji. To wspólne określenie celu i powodu obecności oraz udziału w spotkaniach rekolekcyjnych stanowi ważny element tożsamości osoby uzależnionej. Tutaj rozpoczyna się to przywitaniem wszystkich obecnych - tych nowych i starych poprzez podanie rąk. Ten symboliczny gest pozwala nie czuć się już anonimowo, umacnia atmosferę serdeczności i akceptacji wśród uczestników. Atmosfera rekolekcyjnych spotkań ubogacona wybranymi (charakterystycznymi) pieśniami i piosenkami religijnymi pozwala na nadanie bardzo szczególnego i indywidualnego charakteru tej wspólnocie. W ramach ars celebrandi istotne miejsce zajmuje śpiew liturgiczny. Jak słusznie stwierdza św. Augustyn: „Nowy człowiek zna nowe pieśni. Śpiew jest objawem wesołości. Jeśli wnikliwiej to rozpatrzymy, stwierdzimy, że to sprawa miłości”. Wierni zgromadzeni na przepowiadaniu słowa Bożego pragną oddać chwałę Bogu właśnie poprzez śpiew. Muzyka od początków istnienia Kościoła była ważnym elementem liturgii. Pięknie przygotowana oprawa muzyczna uświęca przeżywane nabożeństwo i pomaga w skupieniu na modlitwie.

W trakcie rekolekcji rozważane są cztery kerygmatyczne prawdy, które zostały zilustrowane na banerach towarzyszących uczestnikom:

1. Bóg mnie kocha;

2. jesteśmy wszyscy grzesznikami;

red. F. L. Cross, E. A. Livingstone, tłum. i aut. dodatkowych haseł E. Czerwińska i in., Warszawa 2004, s. 1220-1221; Encyklopedia katolicka, t. IX, red. A. Bednarek i in., Lublin 2002, s. 993-1042; Encyklopedia biblijna, red. P. J. Achtemeier, oprac. P. Pachciarek, Warszawa 1999, s. 537-539 (Prymasowska Seria Biblijna); Religia. Encyklopedia PWN, t. 6, red. nauk. T. Cadacz, B. Milerski, Warszawa 2002, s. 62-67; Podręczna encyklopedia biblijna, t. I, red. E. Dąbrowski, Poznań-WarszawaLublin 1999, s. 680-686. 
3. Jezus moim Zbawicielem;

4. Jezus moim Panem.

Wszystkie spotkania rekolekcyjne (piątek wieczorem, sobota rano, sobota wieczorem) za wyjątkiem ostatniego, którym jest wspólnie przeżyta niedzielna Eucharystia, można przedstawić według schematu:

1. przywitanie, wprowadzenie w tematykę spotkania;

2. słuchanie słowa Bożego (odpowiednio dobrane czytania z Nowego Testamentu);

3. homilia (konferencja rekolekcyjna), kończąca się świadectwem osoby świeckiej (trzeźwiejącego alkoholika);

4. prakseologia (gr. praxis - działanie) rekolekcyjna (inscenizacja specyficzne działania);

5. wspólna modlitwa na zakończenie (częściowo spontaniczna).

Pierwsza część spotkania rekolekcyjnego jest bardziej teoretyczna (punkty 1-3), druga zaś bardziej praktyczna (punkty 4-5).

Istotny element pastoralny, który pomaga dobrze przeżyć spowiedź rekolekcyjną, stanowi wydrukowany, szczegółowo przygotowany rachunek sumienia. Jest on dlatego tak bardzo potrzebny, bo człowiek uzależniony to na ogół osoba o zdegenerowanej osobowości, nieposiadająca już właściwej hierarchii wartości. Wiele wymiarów jej egzystencji zostało podporządkowanych (zdegenerowanych) postępującemu uzależnieniu. Alkohol doprowadził w życiu takich osób do głębokich deficytów duchowych, moralnych, społecznych i somatycznych. Rachunek sumienia (załącznik 1) stanowi rodzaj koniecznego przewodnika po świecie duchowych i moralnych wartości. Jest nieodzowną pomocą dla alkoholika przeżywającego proces nawrócenia. Ten rachunek sumienia wręcza się uczestnikom zaraz na początku rekolekcji, aby mieli oni więcej czasu na jego indywidualne przestudiowanie. Wspólnie omawia się go (częściowo) w trakcie sobotniej konferencji, która bezpośrednio przygotowuje do sakramentu pojednania.

Z punktu widzenia homiletycznego cechą charakterystyczną rekolekcji jest to, że kapłan wygłasza homilię (konferencję), która 
stanowi szerszy komentarz do wybranego słowa Bożego. Następnie, po wprowadzeniu kapłana, osoba świecka przekazuje swoje osobiste słowo świadectwa. Tak konstruuje się cała konferencja rekolekcyjna. Ten schemat jest realizowany w spotkaniach piątkowych i sobotnich, które odbywają się bez sprawowania Eucharystii. W niedzielę (ostatni dzień rekolekcyjnych spotkań) sprawowana jest uroczysta Eucharystia, a homilia nie zawiera świadectw osób świeckich i ma formę kazania (komentarz do Ewangelii oraz prawdy niezwiązane z niedzielnymi czytaniami, a istotne dla życia duchowego osób uzależnionych).

\section{Spotkanie I: Bóg mnie kocha}

Rozpoczynamy od kerygmatycznej prawdy o miłości Bożej, aby podkreślić godność człowieka uzależnionego i wzmacniać tym samym jego zasoby, a nie pogłębiać deficyty. Głównym problemem osób uzależnionych jest niewłaściwa samoocena i często doświadczenie odrzucenia społecznego. Stąd temat Bóg mnie kocha musi zostać teologicznie rozpracowany w perspektywie miłości miłosiernej jako miłości Boga pochylającego się nad każdym człowiekiem i nad ludzką nędzą ${ }^{60}$. W tekście Ewangelii ukazany jest Jezus, objawiający nam

60 Por. „[...] miłość do syna, która wynika z samej istoty ojcostwa, niejako skazuje ojca na troskę o godność syna. Troska ta jest miarą jego miłości, tej miłości, o której później napisze św. Paweł, że «cierpliwa jest, łaskawa jest [...] nie szuka swego, nie unosi się gniewem, nie pamięta złego», że «współweseli się z prawdą [...] we wszystkim pokłada nadzieję [...] wszystko przetrzyma»i że «nigdy nie ustaje» (1 Kor 13, 4-8). Miłosierdzie - tak jak przedstawił je Chrystus w przypowieści o synu marnotrawnym - ma wewnętrzny kształt takiej miłości, tej, którą w języku Nowego Testamentu nazwano agape. Miłość taka zdolna jest do pochylenia się nad każdym synem marnotrawnym, nad każdą ludzką nędzą, nade wszystko zaś nad nędzą moralną, nad grzechem. Kiedy zaś to czyni, ów, który doznaje miłosierdzia, nie czuje się poniżony, ale odnaleziony $\mathrm{i}$ «dowartościowany». Ojciec ukazuje mu nade wszystko radość z tego, że «się odnalazł», z tego, że «ożył». A ta 
każdym słowem, gestem, a wręcz uderzeniem serca miłosierdzie Boga. Tę prawdę akcentuje konferencja rekolekcyjna, rozbudowując słowa papieża Franciszka z bulli Misericordiae vultus:

Znaki, które czyni przede wszystkim w stosunku do grzeszników, do biednych, wyłączonych, chorych i cierpiących, są naznaczone miłosierdziem. Wszystko w Nim mówi o miłosierdziu. Nie ma też w Nim czegoś, co byłoby pozbawione współczucia. ( $\mathrm{nr} 8$ )

Ta fundamentalna dla wiary chrześcijańskiej prawda często we współczesnym świecie jest dewaluowana, sprowadzona do emocjonalnych błahostek. Jednak szczególnie dla osób uzależnionych konieczne jest, by na nowo została ona wypowiedziana i przyjęta.

Rekolekcje kapłan rozpoczyna w ciszy, zapalając paschał - znak żywej obecności Chrystusa zmartwychwstałego pośród wierzących.

Słowo Boże (Rz 8, 31-39):

Cóż więc na to powiemy? Jeżeli Bóg z nami, któż przeciwko nam? On, który nawet własnego Syna nie oszczędził, ale Go za nas wszystkich wydał, jakże miałby wraz z Nim i wszystkiego nam nie darować? Któż może wystąpić z oskarżeniem przeciw tym, których Bóg wybrał? Czyż Bóg, który usprawiedliwia? Któż może wydać wyrok potępienia? Czy Chrystus Jezus, który poniósł za nas śmierć, co więcej - zmartwychwstał, siedzi po prawicy Boga i przyczynia się za nami? Któż nas może odłączyć od miłości Chrystusowej? Utrapienie, ucisk czy prześladowanie, głód czy nagość, niebezpieczeństwo czy miecz? Jak to jest napisane: z powodu Ciebie zabijają nas przez cały dzień, uważają nas za owce przeznaczone na rzeź. Ale we wszystkim tym odnosimy pełne

radość wskazuje na dobro nienaruszone: przecież syn, nawet i marnotrawny, nie przestał być rzeczywistym synem swego ojca; wskazuje także na dobro odnalezione z powrotem: takim dobrem był w wypadku marnotrawnego syna powrót do prawdy o sobie samym". (Dives in misericordia, 6) 
zwycięstwo dzięki Temu, który nas umiłował. I jestem pewien, że ani śmierć, ani życie, ani aniołowie, ani Zwierzchności, ani rzeczy teraźniejsze, ani przyszłe, ani Moce, ani co wysokie, ani co głębokie, ani jakiekolwiek inne stworzenie nie zdoła nas odłączyć od miłości Boga, która jest w Chrystusie Jezusie, Panu naszym.

Ewangelia (Łk 10, 30-35):

Jezus nawiązując do tego, rzekł: «Pewien człowiek schodził z Jerozolimy do Jerycha i wpadł w ręce zbójców. Ci nie tylko, że go obdarli, lecz jeszcze rany mu zadali i zostawiwszy na pół umarłego, odeszli. Przypadkiem przechodził tą drogą pewien kapłan; zobaczył go i minął. Tak samo lewita, gdy przyszedł na to miejsce i zobaczył go, minął. Pewien zaś Samarytanin, będąc w podróży, przechodził również obok niego. Gdy go zobaczył, wzruszył się głęboko: podszedł do niego i opatrzył mu rany, zalewając je oliwą i winem; potem wsadził go na swoje bydlę, zawiózł do gospody i pielęgnował go. Następnego zaś dnia wyjął dwa denary, dał gospodarzowi i rzekł: „Miej o nim staranie, a jeśli co więcej wydasz, ja oddam tobie, gdy będę wracal"».

Tak dobrane czytanie oraz Ewangelia mają skierować uwagę osób uczestniczących w rekolekcjach na otwarte serce Boga, źródło miłości miłosiernej. Boga, który przepełniony miłością pozwolił się przybić do krzyża ${ }^{61}$. Przypowieść o miłosiernym Samarytaninie ma bardzo wymowną symbolikę. Przedstawienie rozbójników, którzy prawie doprowadzają do śmierci owego pewnego człowieka, może

61 Por. „Mężowie izraelscy, słuchajcie tego, co mówię: Jezusa Nazarejczyka, Męża, którego posłannictwo Bóg potwierdził wam niezwykłymi czynami, cudami i znakami, jakich Bóg przez Niego dokonał wśród was, o czym sami wiecie, tego Męża, który z woli postanowienia i przewidzenia Bożego został wydany, przybiliście rękami bezbożnych do krzyża i zabiliście. Lecz Bóg wskrzesił Go, zerwawszy więzy śmierci, gdyż niemożliwe było, aby ona panowała nad Nim". (Dz 2, 22-24) 
być odczytywane jako odzwierciedlenie tego, co z człowiekiem uzależnionym czyni spożywany w nadmiarze alkohol. Przypowieść przedstawia również obraz osoby uzależnionej w postaci pobitego człowieka, który aby przeżyć, potrzebuje pomocy miłosiernego Samarytanina - jest nim sam Bóg, który nie potrafi przestać kochać człowieka bez względu na to, jakich win się dopuścił. Krzyż jest świadectwem miłości - tak Bóg cię umiłował, że pozwolił się za ciebie przybić do krzyża. Tak kocha, że zmartwychwstał. I chce każdego tą miłością ogarnąć.

W czasie rekolekcji każdą homilię głoszoną przez kapłana wieńczy świadectwo. Jest ono żywym znakiem działania Boga w życiu indywidualnego człowieka. Odpowiednio przygotowane i przepracowane, wskazuje na niepojętą miłość Boga do wszystkich ludzi, Boga, który jest zaangażowany w każdy ludzki los i nie pozostaje obojętny na szczerą modlitwę potrzebującego. To jednocześnie moment bardzo intymny, głęboko odsłaniający ludzkie zranienia i braki. Konieczne jest, aby wszyscy uczestniczący w rekolekcjach zachowali w swoich sercach, w tajemnicy, usłyszane słowo. Istotny element wprowadzający w słuchanie świadectwa stanowi wyjaśnienie uczestnikom, że Bóg znajduje indywidualny sposób poruszenia serca każdego człowieka. Sposoby otwarcia na Boga i Jego słowo każdy chrześcijanin musi wypracować dla siebie. Nie ma jednej sprawdzonej recepty i schematu postępowania. Niekiedy metody skuteczne u jednych okazują się zgubne dla innych. Świadectwo powinno budzić wrażliwość człowieka, kreować nowe pomysły rozwiązywania duchowych trudności, wskazywać kierunek. W żadnym jednak wypadku nie może stać się ono jedyną słuszną drogą narzuconą przez mówiącego.

\section{Spotkanie II: Jesteśmy grzeszni}

Znamienne jest zestawienie problematyki grzechu (mój grzech, jestem człowiekiem grzesznym) z symbolem krzyża. Uczestnicy rekolekcji ze związanymi rękoma podchodzą do krzyża, co ma stanowić 
znak uznania swojej grzeszności i pragnienia nawrócenia, a kapłan symbolicznie rozcina te więzy. W ten sposób przekazuje prawdę, iż cała moc przebaczenia wypływa z dzieła paschalnego (ofiara krzyża). Konferencja zbudowana jest na podwójnym odniesieniu do tajemnicy krzyża i nawiązuje do myśli Jana Pawła II wypowiedzianej w czasie konsekracji bazyliki Bożego Miłosierdzia w Krakowie-Łagiewnikach 17 sierpnia 2005 roku:

„Nadchodzi [...] godzina, owszem, już jest, kiedy to prawdziwi czciciele będą oddawać cześć Ojcu w Duchu i prawdzie, a takich to czcicieli chce mieć Ojciec" (J 4, 23). Kiedy odczytujemy te słowa Pana Jezusa w sanktuarium Miłosierdzia Bożego, w szczególny sposób uświadamiamy sobie, że tu człowiek nie może stanąć inaczej jak w Duchu i prawdzie. To Duch Święty, Pocieszyciel i Duch Prawdy, wprowadza nas na drogi Bożego miłosierdzia. Przekonując świat „o grzechu, o sprawiedliwości i o sądzie" (J 16,8), równocześnie odsłania pełnię zbawienia w Chrystusie. To przekonywanie o grzechu dokonuje się w dwojakim odniesieniu do krzyża Chrystusa. Z jednej strony Duch Święty pozwala nam przez krzyż Chrystusa poznać grzech, każdy grzech, w pełnej skali zła, jakie w sobie zawiera i kryje. Z drugiej strony przez krzyż Chrystusa Duch Święty pozwala nam zobaczyć grzech w świetle mysterium pietatis, czyli miłosiernej, przebaczającej miłości Boga. (por. Dominum et vivificantem, 32)

Czytanie (Dz 4, 8-12):

Wtedy Piotr napełniony Duchem Świętym powiedział do nich: «Przełożeni ludu i starsi! Jeżeli przesłuchujecie nas dzisiaj w sprawie dobrodziejstwa, dzięki któremu chory człowiek uzyskał zdrowie, to niech będzie wiadomo wam wszystkim i całemu ludowi Izraela, że w imię Jezusa Chrystusa Nazarejczyka - którego ukrzyżowaliście, a którego Bóg wskrzesił z martwych - że przez Niego ten człowiek stanął przed wami zdrowy. On jest kamieniem, odrzuconym przez was budujących, 
tym, który stał się głowicą węgła. I nie ma w żadnym innym zbawienia, gdyż nie dano ludziom pod niebem żadnego innego imienia, w którym moglibyśmy być zbawieni».

Ewangelia (J 8, 31-36):

Wtedy powiedział Jezus do Żydów, którzy Mu uwierzyli: «Jeżeli będziecie trwać w nauce mojej, będziecie prawdziwie moimi uczniami i poznacie prawdę, a prawda was wyzwoli». Odpowiedzieli Mu: «Jesteśmy potomstwem Abrahama i nigdy nie byliśmy poddani w niczyją niewolę. Jakżeż Ty możesz mówić: „Wolni będziecie?”». Odpowiedział im Jezus: «Zaprawdę, zaprawdę, powiadam wam: Każdy, kto popełnia grzech, jest niewolnikiem grzechu. A niewolnik nie przebywa w domu na zawsze, lecz Syn przebywa na zawsze. Jeżeli więc Syn was wyzwoli, wówczas będziecie rzeczywiście wolni».

Spotkanie wieńczy katecheza o sakramencie pokuty i przypomnienie pięciu warunków dobrej spowiedzi. Na zakończenie szczegółowo omawia się sytuacje, w których nie można otrzymać rozgrzeszenia.

\section{Spotkanie III: Jezus moim zbawicielem (nabożeństwo pokutne)}

Słowo Boże (2 Kor 5, 17-21):

Jeżeli więc ktoś pozostaje w Chrystusie, jest nowym stworzeniem. To, co dawne, minęło, a oto wszystko stało się nowe. Wszystko zaś to pochodzi od Boga, który pojednał nas z sobą przez Chrystusa i zlecił nam posługę jednania. Albowiem w Chrystusie Bóg jednał z sobą świat, nie poczytując ludziom ich grzechów, nam zaś przekazując słowo jednania. Tak więc w imieniu Chrystusa spełniamy posłannictwo jakby Boga samego, który przez nas udziela napomnień. W imię 
Chrystusa prosimy: pojednajcie się z Bogiem! On to dla nas grzechem uczynił Tego, który nie znał grzechu, abyśmy się stali w Nim sprawiedliwością Bożą.

Ewangelia (Mk 2, 1-12):

Gdy po pewnym czasie wrócił do Kafarnaum, posłyszeli, że jest w domu. Zebrało się tyle ludzi, że nawet przed drzwiami nie było miejsca, a On głosił im naukę. Wtem przyszli do Niego z paralitykiem, którego niosło czterech. Nie mogąc z powodu tłumu przynieść go do Niego, odkryli dach nad miejscem, gdzie Jezus się znajdował, i przez otwór spuścili łoże, na którym leżał paralityk. Jezus, widząc ich wiarę, rzekł do paralityka: «Synu, odpuszczają ci się twoje grzechy». A siedziało tam kilku uczonych w Piśmie, którzy myśleli w sercach swoich: «Czemu On tak mówi? On bluźni. Któż może odpuszczać grzechy, oprócz jednego Boga?». Jezus poznał zaraz w swym duchu, że tak myślą, i rzekł do nich: «Czemu nurtują te myśli w waszych sercach? Cóż jest łatwiej: powiedzieć do paralityka: Odpuszczają ci się twoje grzechy, czy też powiedzieć: Wstań, weź swoje łoże i chodź? Otóż, żebyście wiedzieli, iż Syn Człowieczy ma na ziemi władzę odpuszczania grzechów - rzekł do paralityka: Mówię ci: Wstań, weź swoje łoże i idź do domu!». On wstał, wziął zaraz swoje łoże i wyszedł na oczach wszystkich. Zdumieli się wszyscy i wielbili Boga, mówiąc: «Jeszcze nigdy nie widzieliśmy czegoś podobnego».

Spotkanie IV: Jezus moim Panem

(Niedzielna Eucharystia)

Modlitwa zawierzenia (na zakończenie kazania):

Panie Jezu, uznając swoją grzeszność, pragnę odwrócić się od moich grzechów. Wierzę, że Ty umarłeś na krzyżu i zmartwychwstałeś. 
Zapraszam Cię, Jezu, abyś wszedł do mojego życia. Zapraszam Cię, abyś teraz wszedł do mojego życia. Pragnę być posłuszny Twojej woli i pragnę Cię naśladować. Wyznaję, że Ty jesteś Panem i Zbawicielem mojego życia. Proszę cię, Jezu, abyś mocą Ducha Świętego przemienił moje życie. Spraw, bym był jak Maryja sługą Twojego słowa. Ponieważ to jest jedyny sposób, by być naprawdę wolnym. Chcę Ci być wiernym na zawsze.

Kompletny scenariusz rekolekcyjnych spotkań znajduje się w załączniku 2 do niniejszego artykułu.

\section{Zakończenie}

Jak pisze ks. Oskwarek:

w samoświadomości Ruchu Światło-Życie zagadnienie wolności i wyzwolenia człowieka ze wszystkiego, co uwłacza ludzkiej godności, stoi od samego początku istnienia Ruchu na naczelnym miejscu wśród celów formacji. Bardzo mocno zwraca się uwagę na walkę z polskimi plagami narodowymi, zgodnie z tym, co zostało powiedziane przez Kardynała Stefana Wyszyńskiego w Ślubach Jasnogórskich w Częstochowie podczas obchodów tysiąclecia chrześcijaństwa w Polsce W 1966 r. $^{62}$

Dojrzewanie tych wszystkich idei wyzwolenia zaowocowało powstaniem w roku 1979 programu Krucjaty Wyzwolenia Człowieka. Co prawda nie utożsamia się ona $\mathrm{z}$ samym ruchem, ale stanowi integralne jego dzieło i może wspomagać jego formację podstawową. Ten właśnie program stoi u podstaw homiletyczno-pastoralnych założeń cyklicznych rekolekcji prowadzonych dla pacjentów Szpitala 
im. dr. Józefa Babińskiego w Krakowie. Rekolekcje te odbywają się zasadniczo sześć razy w roku, już od ponad dwudziestu lat. Skorzystało z nich na przestrzeni tego czasu ponad 5 tys. osób uzależnionych i może liczniejsza jeszcze grupa osób cierpiących na współuzależnienie. Wielu naszych pacjentów trwa w trzeźwości już blisko dwadzieścia lat. Niejeden regularnie przyjeżdża na te rekolekcje mimo obowiązków i pracy zawodowej.

Do tej pory nie wydano tekstów rekolekcyjnych konferencji i nie ukazało się żadne teologiczne opracowanie tej formy działalności pastoralnej. Niniejszy artykuł stanowi mały ku temu przyczynek. Jest również formą podziękowania ks. Mirosławowi Żakowi, wieloletniemu duszpasterzowi osób uzależnionych w archidiecezji krakowskiej i autorowi opisanych rekolekcji, za dwudziestoletnią pracę z chorymi w naszym Szpitalu. 


\section{Załącznik 1}

\section{Przygotowanie do spowiedzi}

Pierwszym darem, jaki Pan Jezus po swoim zmartwychwstaniu podarował ludziom, był sakrament pojednania. Chrystus ustanowił go, mówiąc do apostołów: „Weźmijcie Ducha Świętego, którym grzechy odpuścicie, są im odpuszczone, a którym zatrzymacie, są im zatrzymane" (J 20, 22-23). W tym sakramencie człowiek, który przez grzech oddalił się od Boga, wraca do domu Ojca i odzyskuje utraconą więź z Bogiem. Grzech polega na świadomym i dobrowolnym przekroczeniu przykazań Bożych. Jest zawsze raną zadaną samemu sobie, drugiemu człowiekowi, a przede wszystkim jest raną zadaną Bogu, który będąc miłością, boleje, gdy Jego najpiękniejsze stworzenie niszczy siebie. Bóg, jak miłosierny Samarytanin, pochyla się nad człowiekiem, wyciąga do nas ręce i zachęca do nawrócenia i pojednania. Chrystus woła: „Nawracajcie się i wierzcie w Ewangelię”, a Święty Paweł zachęca: „Tak więc w imieniu Chrystusa spełniamy posłannictwo jakby Boga samego, który przez nas udziela napomnień. W imię Chrystusa prosimy - pojednajcie się z Bogiem" (2 Kor 5, 20). Odpuszczenie grzechów, które poprzez sakrament pojednania może otrzymać grzesznik, swoje źródło ma w męce i śmierci Jezusa na krzyżu, który modlił się: „Ojcze, przebacz im, bo nie wiedzą, co czynią" (Łk 23, 34).

Przebaczenie grzechów w sakramencie pojednania jest związane ze spełnieniem przez grzesznika pewnych warunków. Katechizm Kościoła katolickiego podaje ich pięć:

1. rachunek sumienia, czyli przypomnienie sobie grzechów popełnionych od ostatniej dobrej spowiedzi;

2. żal za grzechy, czyli postawa serca, w której człowiek boleje nad obrażeniem Boga. Żal ma mieć charakter nadprzyrodzony, tzn. winien odnosić się do Boga. Nie jest żalem smutek, że podczas jazdy po pijanemu zniszczyliśmy samochód. W takiej sytuacji żal 
nadprzyrodzony oznacza smutek duszy z powodu narażania życia, które jest darem Boga;

3. mocne postanowienie poprawy, czyli postawa nawrócenia z pragnieniem zerwania z popełnianym dotąd grzechem. Postanowienie powinno obejmować wszystkie grzechy ciężkie, jakie się popełniło;

4. szczera spowiedź. Oznacza wyznanie przed kapłanem grzechów śmiertelnych z podaniem ich przybliżonej liczby lub częstotliwości popełniania. Zaleca się również wyznanie grzechów lekkich. W przypadku wątpliwości, czy grzech jest ciężki, czy lekki, należy tę wątpliwość wyznać;

5. zadośćuczynienie Bogu i bliźniemu jest wypełnieniem pokuty zadanej przez kapłana i, w miarę możliwości, naprawieniem krzywd, które się wyrządziło bliźnim, np. zwrócenie skradzionej rzeczy, odwołanie oszczerstwa.

Spowiedź z jej wszystkimi warunkami powinna być poprzedzona modlitwa, zwłaszcza do Ducha Świętego, aby On dopomógł nam dobrze skorzystać z tego sakramentu.

Rachunek sumienia - na podstawie trzech grup grzechów: 1. wobec Boga, 2. wobec bliźniego, 3. wobec samego siebie.

Oprócz odpowiedzi na poniższe pytania odpowiedz sobie: „Co jeszcze niepokoi twoje sumienie?”.

Grzechy wobec Boga

Czy wierzę, że Bóg stał się człowiekiem i umarł na krzyżu dla odpuszczenia moich grzechów?

Czy modlę się systematycznie?

Czy nie wątpiłem w istnienie Boga?

Czy nie bluźniłem i nie przeklinałem Pana Boga?

Czy dobrze się spowiadałem, bez zatajenia grzechów, ze szczerym żalem i postanowieniem poprawy?

Czy nie dopuściłem się świętokradztwa przez przyjęcie Komunii Świętej w grzechu ciężkim, uczestnictwo po pijanemu we mszy świętej, niszczenie znaków religijnych (obrazów, rzeźb), kradzież w kościele? 
Czy nie wierzyłem we wróżby?

Czy nie uczestniczyłem w wywoływaniu duchów i w innych seansach spirytystycznych?

Czy nie wierzyłem w zabobony?

Czy nie przypisywałem cudownych mocy jakimś rzeczom?

Czy nie uczestniczyłem w spotkaniach jakiejś sekty?

Czy nie wyśmiewałem i nie lekceważyłem Boga i ludzi wierzących?

Czy nie przysięgałem fałszywie $z$ wezwaniem Pana Boga na świadka?

Czy nie wzywałem imienia Boga podczas pijaństwa?

Czy nie zaniedbywałem uczestniczenia we mszy świętej w niedzielę i święta?

Czy nie wątpiłem w Boże miłosierdzie i przebaczenie grzechów?

Czy nie odrzucam jakichś prawd głoszonych przez Kościół?

Czy nie twierdziłem, że Bóg nie może mi przebaczyć?

Czy nie byłem zuchwały wobec Boga, twierdząc: „Mogę grzeszyć, Bóg i tak mi przebaczy"?

Czy mówiąc: „Jestem wierzący” swoim zachowaniem nie ośmieszałem wiary?

Jakie rzeczy były ważniejsze dla mnie niż Bóg?

Czy w niedzielę nie wykonywałem $\mathrm{z}$ własnej woli ciężkich prac?

Czy nie wzywałem imienia Boga, Matki Najświętszej i świętych bez potrzeby?

Grzechy wobec bliźnich

Czy nie ma ludzi, których nienawidzę?

Czy nie pobiłem kogoś?

Czy nie dopuściłem się gwałtu?

Czy nie znęcałem się nad kimś?

Czy nie kłamałem o innych ludziach?

Czy przez obmowę nie popsułem komuś opinii?

Czy nie zdradzałem swego współmałżonka/i?

Jaki dawałem przykład dzieciom? 
Czy nie lekceważyłem swoich rodziców?

Czy nie przyczyniłem się do zabicia nienarodzonego dziecka?

Czy nie ukradłem czegoś?

Czy nie niszczyłem cudzych rzeczy?

Jak wypełniam przysięgę małżeńską?

Czy troszczę się o religijne wychowanie moich dzieci?

Jaki jestem wobec swoich pracowników? Czy ich nie wykorzystuję?

Czy pomagam moim starym rodzicom?

Czy żyję w zgodzie ze swoim rodzeństwem?

Czy nie jestem zbyt surowy lub zbyt pobłażliwy wobec swoich dzieci?

Czy nie doprowadziłem kogoś do ubóstwa, rozpaczy?

Czy potrafiłem dzielić się tym, co posiadam, z uboższymi?

Czy nie narażałem życia swojego i innych przez jazdę samochodem po pijanemu lub lekceważąc przepisy ruchu drogowego?

Czy nie niszczyłem własności społecznej i przyrody?

Czy nie namawiałem innych do kradzieży, rozboju, gwałtu?

Grzechy wobec samego siebie

Czy nie niszczyłem własnego zdrowia?

Czy nie zaniedbywałem swojego życia religijnego i duchowego rozwoju?

Czy nie popełniałem samogwałtu?

Czy nie uprawiałem hazardu?

Czy nie uczestniczyłem w orgiach?

Czy nie pragnąłem, planowałem jakiegoś grzechu?

Czy nie popadałem w rozpacz?

Czy nie korzystałem $\mathrm{z}$ wydawnictw pornograficznych?

Czy nie zaniedbywałem swoich obowiązków zawodowych?

Czy nie leniłem się?

Czy nie poniżałem innych ludzi?

Czy nie marnowałem swoich pieniędzy?

Czy nie korzystałem z usług domów publicznych, agencji rozrywkowych? 
Czy nie próbowałem popełnić samobójstwa?

Czy nie zadawałem cierpień zwierzętom?

Czy nie marnowałem czasu przez nadmierne oglądanie telewizji, gry komputerowe etc.?

Czy nie zazdrościłem innym powodzenia?

Czy nie byłem chciwy?

Co jeszcze niepokoi twoje sumienie? 


\section{Załącznik 2}

\section{Scenariusz rekolekcji dla pacjentów oddziałów alkoholowych}

Nawiązanie wspólnoty, wspólne określenie celu i znaczenia, dlaczego tu się przebywa i chce wziąć udział. Tutaj rozpoczyna się to przywitaniem wszystkich obecnych - tych nowych i starych.

Nawiązanie wspólnoty poprzez podanie rąk (piosenka: Dobrze, że jesteś) - pokazuje to pewną dynamikę, pozwala nie czuć się wszystkim obecnym anonimowo.

\section{Spotkanie I: Bóg mnie kocha}

W prezbiterium baner z napisem „Bóg mnie kocha”.

Podczas tego spotkania nie sprawuje się Eucharystii.

Ksiądz w sutannie i stule, ciche wejście.

Znak krzyża.

Słowo wprowadzenia. W Aniele Pańskim „Słowo stało się ciałem" - można przez to rozumieć, że każde słowo Boże się spełnia. Jest z nami przez wszystkie dni aż do skończenia świata.

Tłumaczenie szczególnych elementów rekolekcji - „Pan z wami” Eucharystia to spotkanie z Bogiem, chce On spotkać się z każdym $\mathrm{z}$ nas osobiście.

Zapala się paschał - obecność JCH, który jest światłością świata (poza paschałem nie palą się żadne inne świece).

Piosenka: Duchu święty, Duchu Święty, Duchu święty, Duchu Święty - przyjdź i rozpal w nas, i utul nas, miłość nam daj, przyjdź i rozpal nas, i utul nas, miłość nam daj.

Modlitwa spontaniczna wiernych z kościoła, głównego celebransa.

Słowo Boże:

Cóż więc na to powiemy? Jeżeli Bóg z nami, któż przeciwko nam? On, który nawet własnego Syna nie oszczędził, ale Go za nas wszystkich 
wydał, jakże miałby wraz z Nim i wszystkiego nam nie darować? Któż może wystąpić z oskarżeniem przeciw tym, których Bóg wybrał? Czyż Bóg, który usprawiedliwia? Któż może wydać wyrok potępienia? Czy Chrystus Jezus, który poniósł za nas śmierć, co więcej - zmartwychwstał, siedzi po prawicy Boga i przyczynia się za nami? Któż nas może odłączyć od miłości Chrystusowej? Utrapienie, ucisk czy prześladowanie, głód czy nagość, niebezpieczeństwo czy miecz? Jak to jest napisane: $Z$ powodu Ciebie zabijają nas przez cały dzień, uważają nas za owce przeznaczone na rzeź. Ale we wszystkim tym odnosimy pełne zwycięstwo dzięki Temu, który nas umiłował. I jestem pewien, że ani śmierć, ani życie, ani aniołowie, ani Zwierzchności, ani rzeczy teraźniejsze, ani przyszłe, ani Moce, ani co wysokie, ani co głębokie, ani jakiekolwiek inne stworzenie nie zdoła nas odłączyć od miłości Boga, która jest w Chrystusie Jezusie, Panu naszym.

(Rz 8, 31-39)

Piosenka - Zobaczcie, jak wielką miłość Ojciec ofiarował nam. Ewangelia:

Jezus nawiązując do tego, rzekł: «Pewien człowiek schodził z Jerozolimy do Jerycha i wpadł w ręce zbójców. Ci nie tylko, że go obdarli, lecz jeszcze rany mu zadali i zostawiwszy na pół umarłego, odeszli. Przypadkiem przechodził tą drogą pewien kapłan; zobaczył go i minął. Tak samo lewita, gdy przyszedł na to miejsce i zobaczył go, minął. Pewien zaś Samarytanin, będąc w podróży, przechodził również obok niego. Gdy go zobaczył, wzruszył się głęboko: podszedł do niego i opatrzył mu rany, zalewając je oliwą i winem; potem wsadził go na swoje bydlę, zawiózł do gospody i pielęgnował go. Następnego zaś dnia wyjął dwa denary, dał gospodarzowi i rzekł: „Miej o nim staranie, a jeśli co więcej wydasz, ja oddam tobie, gdy będę wracal"». (Łk 10, 30-35)

Konferencja. Na zakończenie świadectwo. 
Po konferencji kapłan wychodzi do zakrystii i przebiera się w albę.

Piosenka: Wielka jest wierność twa, gdy do mnie zbliżasz się.

Modlitwa spontaniczna prowadzona przez diakonię.

Wygaszenie świateł w kaplicy.

Zachęcenie do opuszczenia ławek i znalezienia dla siebie najbardziej odpowiedniego miejsca w kościele. W tym miejscu na pewno znajdzie się ktoś, kto podprowadzi do kapłana, który symbolizuje Boga Ojca. (nastrojowa muzyka) Dwóch mężczyzn w komżach klęczących przed ołtarzem.

Po czasie - zapalenie świateł ołtarza głównego (tylko).

Ksiądz w prezbiterium w albie.

Mężczyźni podprowadzają do księdza kolejne osoby z kościoła. Ksiądz każdego przytula i mówi coś do ucha.

Każdy, kto schodzi od księdza, podchodzi do pani stojącej pod ambonką - ściska się z nią i dostaje obrazek.

Każdy przyprowadzony jest trzymany za ramiona.

Symboliczne trzymanie za ramiona, uścisk przyjaciela.

Ksiądz wychodzi. Zapala się żyrandol.

Ksiądz wchodzi do kościoła. Wszyscy wychodzą z ławek, łapią się za ręce i tworzą krąg w środku kościoła. Przy akompaniamencie gitary śpiewana jest modlitwa Ojcze nasz. Modlitwa dziękczynna.

Śpiewana fraza: Abba, Ojcze.

Wszyscy siadają. Ksiądz od ambony.

Wszyscy dostali obrazek będący reprodukcją obrazu Ubiczowanego Chrystusa, namalowanego przez świętego brata Alberta. Historia Alberta.

$\mathrm{Na}$ odwrocie: „Bo góry mogą ustąpić i pagórki się zachwiać, ale miłość moja nie odstąpi od ciebie i nie zachwieje się moje przymierze pokoju, mówi Pan, który ma litość nad tobą. ( $\mathrm{Iz} 54,10)$

Zaproszenie na jutro.

Błogosławieństwo.

Piosenka: Przeogromna ziemio. 
Nasze słabości potrzebują Bożej ingerencji. Każdemu wchodzącemu do kościoła są wiązane sznurkiem ręce (dwóch panów w komżach). Akompaniament muzyki. Komentarz o zniewoleniu grzechem i uwikłaniu w jego działanie.

Czytanie:

Wtedy Piotr napełniony Duchem Świętym powiedział do nich: «Przełożeni ludu i starsi! Jeżeli przesłuchujecie nas dzisiaj w sprawie dobrodziejstwa, dzięki któremu chory człowiek uzyskał zdrowie, to niech będzie wiadomo wam wszystkim i całemu ludowi Izraela, że w imię Jezusa Chrystusa Nazarejczyka - którego ukrzyżowaliście, a którego Bóg wskrzesił z martwych - że przez Niego ten człowiek stanął przed wami zdrowy. On jest kamieniem, odrzuconym przez was budujących, tym, który stał się głowicą węgła. I nie ma w żadnym innym zbawienia, gdyż nie dano ludziom pod niebem żadnego innego imienia, w którym moglibyśmy być zbawieni».

(Dz 4, 8-12)

(W tym dniu można również czytać: $\mathrm{Rz} 7,14-20$ )

Ewangelia:

Wtedy powiedział Jezus do Żydów, którzy Mu uwierzyli: «Jeżeli będziecie trwać w nauce mojej, będziecie prawdziwie moimi uczniami i poznacie prawdę, a prawda was wyzwoli». Odpowiedzieli Mu: «Jesteśmy potomstwem Abrahama i nigdy nie byliśmy poddani w niczyją niewolę. Jakżeż Ty możesz mówić: „Wolni będziecie?”». Odpowiedział im Jezus: «Zaprawdę, zaprawdę, powiadam wam: Każdy, kto popełnia grzech, jest niewolnikiem grzechu. A niewolnik nie przebywa w domu na zawsze, lecz Syn przebywa na zawsze. Jeżeli więc Syn was wyzwoli, wówczas będziecie rzeczywiście wolni».

(J 8, 31-36) 
Konferencja. Sznurki na rękach są symbolem zniewolenia, tak samo jak grzech.

Grzech jest nie tylko osobisty, ale też społeczny - żyjemy w czasach, kiedy grzech społeczny jest coraz częściej widoczny. Skutkiem grzechu jest nie tylko zerwanie relacji z Bogiem; narusza on również wolność osobistą człowieka, rani też relacje międzyludzkie.

Grzech to ukrzyżowanie Chrystusa. Na zakończenie świadectwo.

Kapłan ubrany w albę i fioletową stułę. Przed ołtarzem na stoliczku nakrytym białym obrusem leży mały krzyż. Każdy z obecnych podchodzi do krzyża i całuje go. Po pocałunku kapłan przecina nożyczkami sznurki wiążące ręce. Symboliczny znak, że Ukrzyżowany uwalnia nas od wszelkiego zniewolenia (każdy otrzymuje kartkę $\mathrm{z}$ rachunkiem sumienia i warunkami dobrej spowiedzi).

Katecheza o sakramencie pokuty

Przypomnienie pięciu warunków dobrej spowiedzi.

Warunki otrzymania rozgrzeszenia. Problem związków niesakramentalnych. Kiedy kapłan może nie udzielić rozgrzeszenia.

\section{Spotkanie III: Jezus moim zbawicielem}

Nabożeństwo pokutne.

$\mathrm{Na}$ ołtarzu obrus i korporał - przygotowanie do wystawienia Eucharystii. Przed ołtarzem mały stoliczek nakryty białym obrusem.

Ksiądz w albie i fioletowej stule. Zapalenie paschału.

Modlitwa spontaniczna. Piosenka Duchu Święty.

Słowo Boże

Jeżeli więc ktoś pozostaje w Chrystusie, jest nowym stworzeniem. To, co dawne, minęło, a oto wszystko stało się nowe. Wszystko zaś to pochodzi od Boga, który pojednał nas z sobą przez Chrystusa i zlecił nam posługę jednania. Albowiem w Chrystusie Bóg jednał z sobą świat, nie poczytując ludziom ich grzechów, nam zaś przekazując słowo jednania. 
Tak więc w imieniu Chrystusa spełniamy posłannictwo jakby Boga samego, który przez nas udziela napomnień. W imię Chrystusa prosimy: pojednajcie się z Bogiem! On to dla nas grzechem uczynił Tego, który nie znał grzechu, abyśmy się stali w Nim sprawiedliwością Bożą. (2 Kor 5, 17-21)

Piosenka: Mój Zbawiciel bardzo kocha mnie. Ewangelia:

Gdy po pewnym czasie wrócił do Kafarnaum, posłyszeli, że jest w domu. Zebrało się tyle ludzi, że nawet przed drzwiami nie było miejsca, a On głosił im naukę. Wtem przyszli do Niego z paralitykiem, którego niosło czterech. Nie mogąc z powodu tłumu przynieść go do Niego, odkryli dach nad miejscem, gdzie Jezus się znajdował, i przez otwór spuścili łoże, na którym leżał paralityk. Jezus, widząc ich wiarę, rzekł do paralityka: «Synu, odpuszczają ci się twoje grzechy». A siedziało tam kilku uczonych w Piśmie, którzy myśleli w sercach swoich: «Czemu On tak mówi? On bluźni. Któż może odpuszczać grzechy, oprócz jednego Boga?». Jezus poznał zaraz w swym duchu, że tak myślą, i rzekł do nich: «Czemu nurtują te myśli w waszych sercach? Cóż jest łatwiej: powiedzieć do paralityka: Odpuszczają ci się twoje grzechy, czy też powiedzieć: Wstań, weź swoje łoże i chodź? Otóż, żebyście wiedzieli, iż Syn Człowieczy ma na ziemi władzę odpuszczania grzechów - rzekł do paralityka: Mówię ci: Wstań, weź swoje łoże i idź do domu!». On wstał, wziął zaraz swoje łoże i wyszedł na oczach wszystkich. Zdumieli się wszyscy i wielbili Boga, mówiąc: «Jeszcze nigdy nie widzieliśmy czegoś podobnego».

(Mk 2, 1-12)

Konferencja, a po niej wystawienie Najświętszego Sakramentu. Rozpoczęcie sakramentu spowiedzi św. - każda osoba po odbytej spowiedzi zapala od paschału świeczkę i stawia ją na przygotowanym wcześniej stoliku. 
Po zakończonym sakramencie spowiedzi wszyscy stają w kręgu (ołtarz w środku); krótka modlitwa uwielbienia i dziękczynienia. Modlitwa Ojcze nasz.

Śpiew: Abba, Ojcze!

Błogosławieństwo Najświętszym Sakramentem.

Na zakończenie palenie kartek z grzechami, napisanych w ramach przygotowania do sakramentu spowiedzi. W obliczu miłości Boga z naszych grzechów zostaje tyle co ze spalonej kartki papieru.

\section{Spotkanie IV: Jezus moim Panem (Eucharystia)}

Czytania i Ewangelia według kalendarza liturgicznego.

Przy wejściu do kościoła znajdują się koszyczek, kartki i długopisy - każdy wpisuje na kartkę własną intencję mszy świętej. Są one niesione $\mathrm{w}$ procesji $\mathrm{z}$ darami, a w czasie modlitwy różańcowej w pierwsze soboty miesiąca są czytane i przedstawiane Bogu w sanktuarium Świętego Jana Pawła II (godz. 17.0o msza święta, po mszy różaniec).

Kazanie:

Piotr zawsze robił coś nie tak. Chrystus zawsze powołuje grzeszników, a nie świętych.

Powołanie i wezwanie to jedna strona - jest to dar.

Powołanie to odpowiedź na wezwanie.

Piotr często robił coś nie tak, odchodzi, ale zawsze wraca do JCH. Dialog Piotra z Jezusem (J 21; A $ү \alpha \pi \alpha \omega-\varphi \iota \lambda \varepsilon \omega)$.

Modlitwa zawierzenia:

Panie Jezu, uznając swoją grzeszność, pragnę odwrócić się od moich grzechów. Wierzę, że Ty umarłeś na krzyżu i zmartwychwstałeś. Zapraszam Cię, Jezu, abyś wszedł do mojego życia. Zapraszam Cię, abyś teraz wszedł do mojego życia. Pragnę być posłuszny Twojej woli i pragnę Cię naśladować. Wyznaję, że Ty jesteś Panem i Zbawicielem mojego życia. Proszę Cię, Jezu, abyś mocą Ducha Świętego przemienił moje życie. Spraw, bym był jak Maryja sługą Twojego słowa. 
Ponieważ to jest jedyny sposób, by być naprawdę wolnym. Chcę Ci być wiernym na zawsze.

Szczególna modlitwa wiernych:

Wszyscy podchodzą do kapłana, on modli się nad każdym indywidualnie; wręcza po modlitwie zapaloną świecę i akt zawierzenia Jezusowi.

Na zakończenie, powierzając wszystkie intencje Bogu: Pod Twoją obronę.

Procesja $\mathrm{z}$ darami:

koszyczek z intencjami (złożony na ołtarzu);

wino i woda;

chleb eucharystyczny.

Liturgia eucharystyczna. 